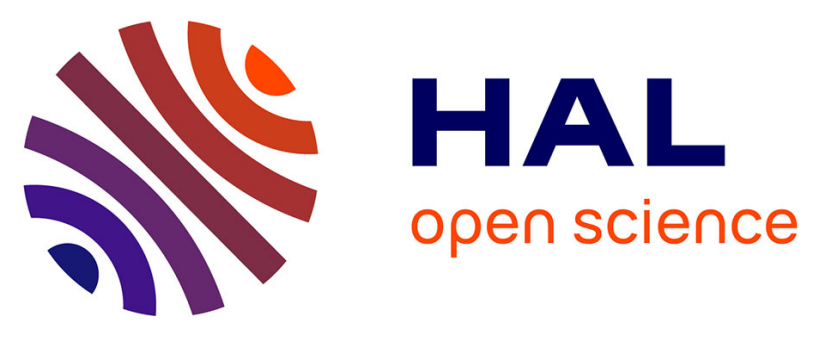

\title{
A 450 year record of spring-summer flood layers in annually laminated sediments from Lake Ammersee (southern Germany)
}

Markus Czymzik, Peter Dulski, Birgit Plessen, Ulrich von Grafenstein, Rudolf Naumann, Achim Brauer

\section{To cite this version:}

Markus Czymzik, Peter Dulski, Birgit Plessen, Ulrich von Grafenstein, Rudolf Naumann, et al.. A 450 year record of spring-summer flood layers in annually laminated sediments from Lake Ammersee (southern Germany). Water Resources Research, 2010, 46 (11), pp.W11528. 10.1029/2009WR008360 . hal-02469310

\section{HAL Id: hal-02469310 https://hal.science/hal-02469310}

Submitted on 6 May 2021

HAL is a multi-disciplinary open access archive for the deposit and dissemination of scientific research documents, whether they are published or not. The documents may come from teaching and research institutions in France or abroad, or from public or private research centers.
L'archive ouverte pluridisciplinaire HAL, est destinée au dépôt et à la diffusion de documents scientifiques de niveau recherche, publiés ou non, émanant des établissements d'enseignement et de recherche français ou étrangers, des laboratoires publics ou privés. 


\title{
A 450 year record of spring-summer flood layers in annually laminated sediments from Lake Ammersee (southern Germany)
}

\author{
Markus Czymzik, ${ }^{1}$ Peter Dulski, ${ }^{1}$ Birgit Plessen, ${ }^{1}$ Ulrich von Grafenstein, ${ }^{2}$ \\ Rudolf Naumann, ${ }^{3}$ and Achim Brauer ${ }^{1}$ \\ Received 7 July 2009; revised 14 July 2010; accepted 9 August 2010; published 17 November 2010.
}

[1] A 450 year spring-summer flood layer time series at seasonal resolution has been established from the varved sediment record of Lake Ammersee (southern Germany), applying a novel methodological approach. The main results are (1) the attainment of a precise chronology by microscopic varve counting, (2) the identification of detrital layers representing flood-triggered fluxes of catchment material into the lake, and (3) the recognition of the seasonality of these flood layers from their microstratigraphic position within a varve. Tracing flood layers in a proximal and a distal core and correlating them by application of the precise chronology provided information on the depositional processes. Comparing the seasonal flood layer record with daily runoff data of the inflowing River Ammer for the period from 1926 to 1999 allowed the definition of an approximate threshold in flood magnitude above which the formation of flood layers becomes very likely. Moreover, it was possible for the first time to estimate the "completeness" of the flood layer time series and to recognize that mainly floods in spring and summer, representing the main flood seasons in this region, are well preserved in the sediment archive. Their frequency distribution over the entire 450 year time series is not stationary but reveals maxima for colder periods of the Little Ice Age when solar activity was reduced. The observed spring-summer flood layer frequency further shows trends similar to those of the occurrence of flood-prone weather regimes since A.D. 1881, probably suggesting a causal link between solar variability and changes in midlatitude atmospheric circulation patterns.

Citation: Czymzik, M., P. Dulski, B. Plessen, U. von Grafenstein, R. Naumann, and A. Brauer (2010), A 450 year record of spring-summer flood layers in annually laminated sediments from Lake Ammersee (southern Germany), Water Resour. Res., 46, W11528, doi:10.1029/2009WR008360.

\section{Introduction}

[2] Assumptions about an increase in extreme flood events due to an intensified hydrological cycle caused by global warming are still under discussion and must be better verified. Statistical flood analyses indicate that simple mechanistic explanations are not straightforward and that complex seasonal [Mudelsee et al., 2003] and regional [Petrow and Merz, 2009] effects have to be considered. Some historical flood records even indicate that flood frequencies were higher during colder periods [Knox, 1993; Glaser and Stangl, 2004], challenging the hypothesis of a correlation between the frequency of extreme floods and a warmer climate. However, the length of presently available flood time series is not sufficient for a profound understanding of possible relations between flood frequencies and climatic boundary

\footnotetext{
${ }^{1}$ Section 5.2: Climate Dynamics and Landscape Evolution, GFZ German Research Centre for Geosciences, Potsdam, Germany.

${ }^{2}$ Laboratoire des Sciences du Climat et de l'Environnement, UMR CEA-CNRS, Gif-sur-Yvette, France.

${ }^{3}$ Section 4.2: Inorganic and Isotope Geochemistry, GFZ German Research Centre for Geosciences, Potsdam, Germany.

Copyright 2010 by the American Geophysical Union. 0043-1397/10/2009WR008360
}

conditions. This is largely due to the lack of long-term instrumental flood data; available data rarely exceed a century [Baker, 2006] and thus cover only the period of strongest human interferences in most river catchments.

[3] In addition to the extension of flood time series into the recent past by exploitation of historical archives, natural archives are available that record climate changes and the occurrence of extreme events even much farther back in times without any human activity. Particularly, river and lake sediments have been proven to be suitable long flood records [e.g., Dearing, 1991; Thorndycraft et al., 1998; Dearing et al., 2001; Thorndycraft and Benito, 2006]. These geological archives provide crucial information for a better evaluation of flood occurrences under different climate boundary conditions, which are often not considered for flood frequency calculations assuming a stationary climate [Knox and Kundzewicz, 1997]. However, it must be considered that investigating geological archives focusing on extreme event occurrences is still at its beginning. One key question is the degree of "completeness" to which geological archives record flood events. Filling this gap in knowledge requires calibrating the paleoflood record with instrumental and/or historical flood data. However, merging geological and instrumental time series is not straightforward because of their very different temporal resolutions. A novel approach 
to bridge these gaps in time resolution is to reduce the commonly not better than decadal-scale resolution of geoarchives by utilizing annually laminated lake sediments. Fine, millimeter to submillimeter laminations in lake sediments formed by seasonally varying deposition processes are defined as varves and provide both precise time control by varve counting and climatic and environmental information at seasonal resolution [Brauer and Casanova, 2001; Brauer, 2004].

[4] In varved lake sediments, flood-triggered fluxes of eroded fine catchment material result in the deposition of characteristic detrital layers that can be determined with seasonal precision by their microstratigraphical position within the annual sedimentation cycle [Mangili et al., 2005; Brauer et al., 2008]. However, reconstructing flood time series from lake sediments necessitates a comprehensive understanding of the entire cascade of processes, from sediment erosion and transport in the catchment to distribution and deposition in the lake basin, to rule out other causes for event layer deposition such as slope failure and debris flow [Mangili et al., 2005; Swierczynski et al., 2009].

[5] Lake Ammersee is an ideal location to build up a long flood record because previous work has proven this sediment profile to be a sensitive proxy archive for high-resolution paleotemperature reconstruction [e.g., von Grafenstein et al., 1996, 1999]. Preservation of annual laminations enables accurate detection and precise dating of flood-triggered detrital material in the sediment with seasonal precision. In addition, a wealth of meteorological and hydrological data is available from local authorities to compare the geological and instrumental time series. Therefore, two new short sediment cores have been studied applying a novel methodological approach that combines microfacies analyses, high-resolution element scanning ( $\mu$-XRF), stable isotope data from bulk carbonate samples $\left(\delta^{13} \mathrm{C}_{\text {carb }}\right.$, $\delta^{18} \mathrm{O}_{\text {carb}}$ ), and X-ray diffraction (XRD) analyses [Brauer et al., 2009]. Integrating these analytical techniques enables better and more precise identification and interpretation of flood layers at microscopical scales that previously have not been detected.

\section{Study Site}

[6] Lake Ammersee (533 $\mathrm{m}$ above sea level) is a hardwater lake located in South Germany $\left(48^{\circ} 00^{\prime} \mathrm{N}, 11^{\circ} 07^{\prime} \mathrm{E}\right)$ with a surface area of $47 \mathrm{~km}^{2}$ and a maximum depth of $81.1 \mathrm{~m}$ (Figure 1). The $16.2 \mathrm{~km}$ long and $2.8 \mathrm{~km}$ wide basin is shaped into Tertiary and Quaternary sediments by the Ammersee lobe of the Isar-Loisach glacier [Alefs, 1997]. The catchment of the main tributary River Ammer has a size of $709 \mathrm{~km}^{2}$ and reaches a maximum elevation of $2185 \mathrm{~m}$ above sea level [Ludwig et al., 2003]. The Ammer arises in the Bavarian Calcareous Alps and flows northward through smoothly shaped prealpine flysch, molasse, and late moraine formations [Mangelsdorf and Zelinka, 1973] before entering the lake at its southern end (Figure 1). Detrital sediment is supplied to the lake nearly exclusively by the Ammer River [Alefs, 1997]. Secondary inflows like the River Rott and the Fischbach have negligible effects on the detrital sediment supply into the lake basin [Bayerisches Landesamt für Wasserwirtschaft, 2005]. The Ammer River mouth was artificially displaced for approximately $1 \mathrm{~km}$ to the southeastern part of the lake during channelization of the river bed between A.D. 1920 and A.D. 1924 [Alefs, 1997] (hereafter all dates are given in A.D. notation). Before that time the River Ammer inlet was located at the present-day inlet of the River Rott, a former Ammer tributary (Figure 1).

[7] The Ammer catchment is located in the hydrologic transition zone between maritime North Atlantic and continental climate influenced by both weather regimes related to frequent cyclonic westerly airflow and atmospheric blocking through high-pressure fields [Petrow and Merz, 2009]. The pluvionival runoff regime indicates maximum flow rates during the transition from snowmelt periods in spring to precipitation maxima in summer. Limited storage capacities of the alpine soils and high water tables in the northern valleys of the catchment favor frequent floods dominated by saturation excess overland flow. The steep (relief difference of $1652 \mathrm{~m}$ ) and rather small catchment favors short but high runoff peaks [Ludwig et al., 2003].

\section{Methods}

\subsection{Sediment Coring}

[8] Two short sediment cores (AS 07-P1, $133 \mathrm{~cm}$; AS 07$\mathrm{P} 2,134 \mathrm{~cm}$ ) were retrieved from the deepest part of the lake basin in June 2007 with a modified UWITEC short-core system. Core AS 07-P1 is located in a distal $(6.2 \mathrm{~km})$ and core AS $07-\mathrm{P} 2$ is located in a more proximal $(4.4 \mathrm{~km})$ position toward the Ammer River mouth (Figure 1).

\subsection{Microfacies Analyses}

[9] For microfacies analyses and measurements of seasonal sublayer properties, two overlapping series of 16 thin sections from core AS $07-\mathrm{P} 1$ and 9 thin sections from core AS 07-P2 were investigated using a petrographic microscope (Carl Zeiss-Axiophot, Jena, Germany). Preparation of undisturbed thin sections from wet and soft sediments is a crucial methodological prerequisite to adequately perform microstratigraphical investigations and includes careful freeze-drying and epoxy resin impregnation [Brauer and Casanova, 2001]. The bottom part of core AS 07-P2 was disturbed during core splitting, thus preventing further thin section preparation. Consequently, the investigated interval of this core is shorter. Various magnifications and optical and light conditions were used for microfacies analyses. Thickness measurements of detrital layers were performed at $25 \times$ magnification. Microfacies analyses and description of structural characteristics of detrital layers were not always applicable for very thin detrital layers $(<1 \mathrm{~mm})$. A precise chronology was constructed by calcite varve counting. Short intervals of poor varve preservation were interpolated using annual sedimentation rates as calculated from varve thickness measurements in well-preserved adjacent varve sections.

[10] Owing to the disturbances in the bottom part of core AS 07-P2 and the higher sedimentation rates at this more proximal location, this core covers a shorter time interval than the distal core AS 07-P1. Therefore, precise varve-tovarve correlation including comparison of microfacies is available only for the upper $60 \mathrm{~cm}$ of the distal core AS 07-P1, covering the last 200 years (Figure 2). The older interval of the entire 450 year flood layer record has been established from the bottom part of core AS 07-P1 alone, without the parallel sediment sequence from the proximal site. 


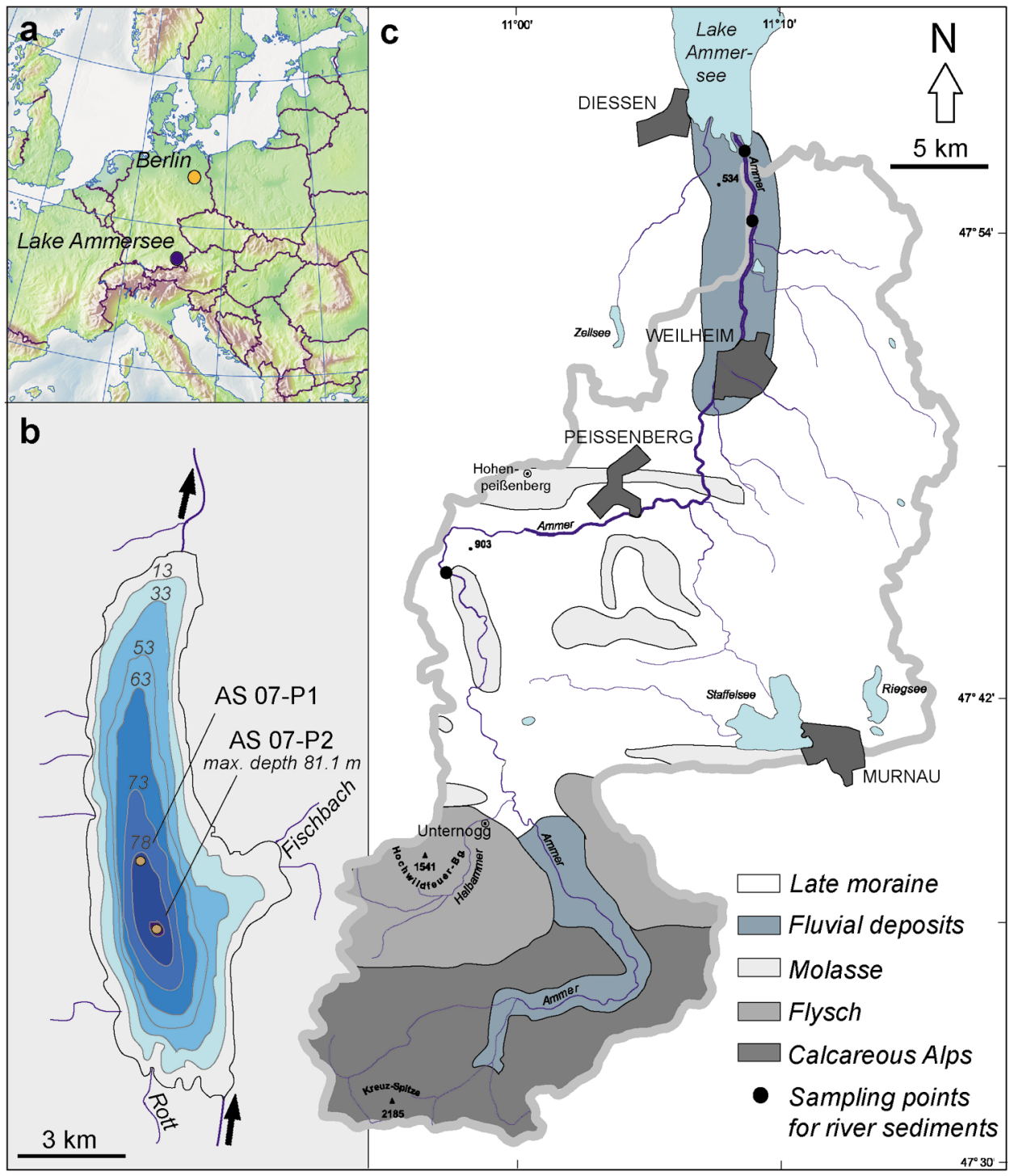

Figure 1. (a) Geographical overview and (b) bathymetric map of Lake Ammersee including positions of cores AS 07-P1 (distal) and AS 07-P2 (proximal). (c) Hydrogeological sketch of the Ammer catchment.

\subsection{Micro X-Ray Fluorescence Scanning, Stable Isotope Ratios from Bulk Carbonates, and X-Ray Diffraction}

[11] Microscopic data have been combined with $\mu$-XRF, stable isotope ratios from bulk carbonate samples $\left(\delta^{18} \mathrm{O}_{\text {carb }}\right.$, $\delta^{13} \mathrm{C}_{\text {carb }}$ ), and XRD. Micro-XRF scanning of major elements $(\mathrm{Mg}, \mathrm{Al}, \mathrm{Si}, \mathrm{P}, \mathrm{S}, \mathrm{Cl}, \mathrm{K}, \mathrm{Ca}, \mathrm{Ti}, \mathrm{Mn}, \mathrm{Fe}, \mathrm{Sr})$ at $200 \mu \mathrm{m}$ resolution was carried out on the fresh sediment surface of both cores with an Eagle III BKA $\mu$-XRF spectrometer (Röntgenanalytik Messtechnik GmbH, Taunusstein, Germany). The resulting time resolution is about 10 data points for each varve (i.e., year). Scanner data can be precisely matched to microfacies data because both data sets were measured from the same section plane of the splitted cores [Brauer et al., 2009]. For single-line measurements the tube voltage was set at $40 \mathrm{kV}$, with a tube current of $450 \mu \mathrm{A}$. The dwell time for each measurement was $30 \mathrm{~s}$. Each data point reflects the mean element intensity of one measured spot, expressed as counts per second (cps).

[12] Stable oxygen and carbon isotope ratios of bulk carbonate samples were measured with a GasBench II (Thermo Electron, Bremen, Germany) connected to a DELTAplusXL Isotope Ratio Mass Spectrometer (ThermoFisher Scientific, Waltham, MA, USA) working in continuous flow mode. Samples were extracted from freeze-dried and powdered $5 \mathrm{~mm}$ sediment slices of both cores representing a 2 year resolution. Depending on the carbonate content, 0.25 to $0.5 \mathrm{mg}$ of sample material was loaded into $10 \mathrm{ml}$ vials. After automatic flushing of the vials with $\mathrm{He}$, the samples were treated with $100 \%$ phosphoric acid at $75^{\circ} \mathrm{C}$ for $60 \mathrm{~min}$ in the GasBench preparation system following the analytical procedure described by Spötl and Vennemann [2003]. Isotopic compositions of the samples are given relative to the Vienna Peedee belemnite standard in the $\delta$ notation. $\delta_{\mathrm{A}}=\left(R_{\mathrm{SA}} / R_{\mathrm{ST}}-1\right) \times 10^{3}(\%)$, where $R_{\mathrm{SA}}$ is the 

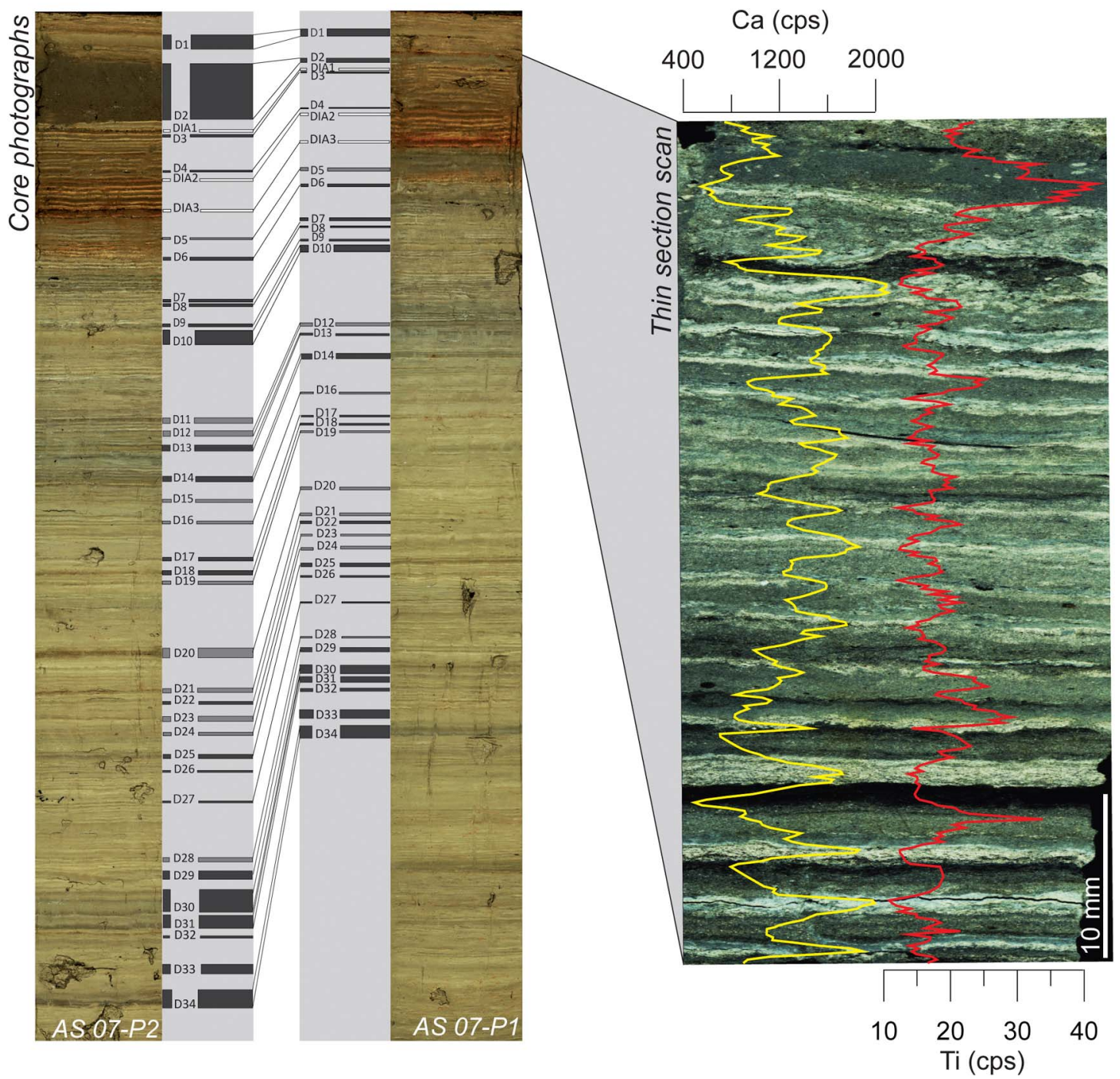

Figure 2. (left) Varve-to-varve correlation of detrital layers D1 to D34 and monospecific diatom layers DIA1 to DIA3 (white bars; not mentioned in the text) between core AS 07-P1 and core AS 07-P2. Dark gray bars mark microscopically correlated detrital layers showing both the same microstratigraphic position and microfacies. Correlating detrital layers indicated by light gray bars exhibit different microfacies in each core. (right) Thin section scan with polarizing filter but without microscopic magnification showing calcite varves with intercalated detrital and diatom layers (AS 07-P1;3-8 cm core depth). Distinct positive $\mu$-XRF excursions of the element Ti (counts per second; cps) indicate detrital layers. Calcite layers are represented by positive $\mathrm{Ca}(\mathrm{cps})$ and darker layers by small positive $\mathrm{Ti}$ (cps) excursions.

isotopic ratio $\left({ }^{13} \mathrm{C} /{ }^{12} \mathrm{C},{ }^{18} \mathrm{O} /{ }^{16} \mathrm{O}\right)$ of the sample and $R_{\mathrm{ST}}$ is that of the standard. Calibration was performed against three international reference standards (NBS 19, CO1, CO8). The $1 \sigma$ precision of replicate measurements of NSB 19 is $0.06 \%$ for $\delta^{13} \mathrm{C}$ and $0.08 \%$ for $\delta^{18} \mathrm{O}$.

[13] XRD analyses of 11 representative samples selected by microscopic observations were carried out using a Siemens Diffraktometer 5000 (Siemens, Karlsruhe, Germany). Seven measurements were performed on $1 \mathrm{~cm}$ sediment samples reflecting the different types of detrital microfacies. Four measurements were carried out on $1 \mathrm{~cm}$ bulk samples of regularly varved sediment, thus representing 4-5 varve years.

\section{Results}

\subsection{Varve Microfacies and Chronology}

[14] The sediments consist of calcite varves with intercalated detrital layers [Alefs, 1997; Alefs and Müller, 1999]. Ninety-seven percent of the sediment profile exhibits wellknown structures of calcite varves consisting of couplets of discrete light calcite layers and darker organic layers [e.g., Lotter and Lemcke, 1999; Brauer et al., 2008]. Since 


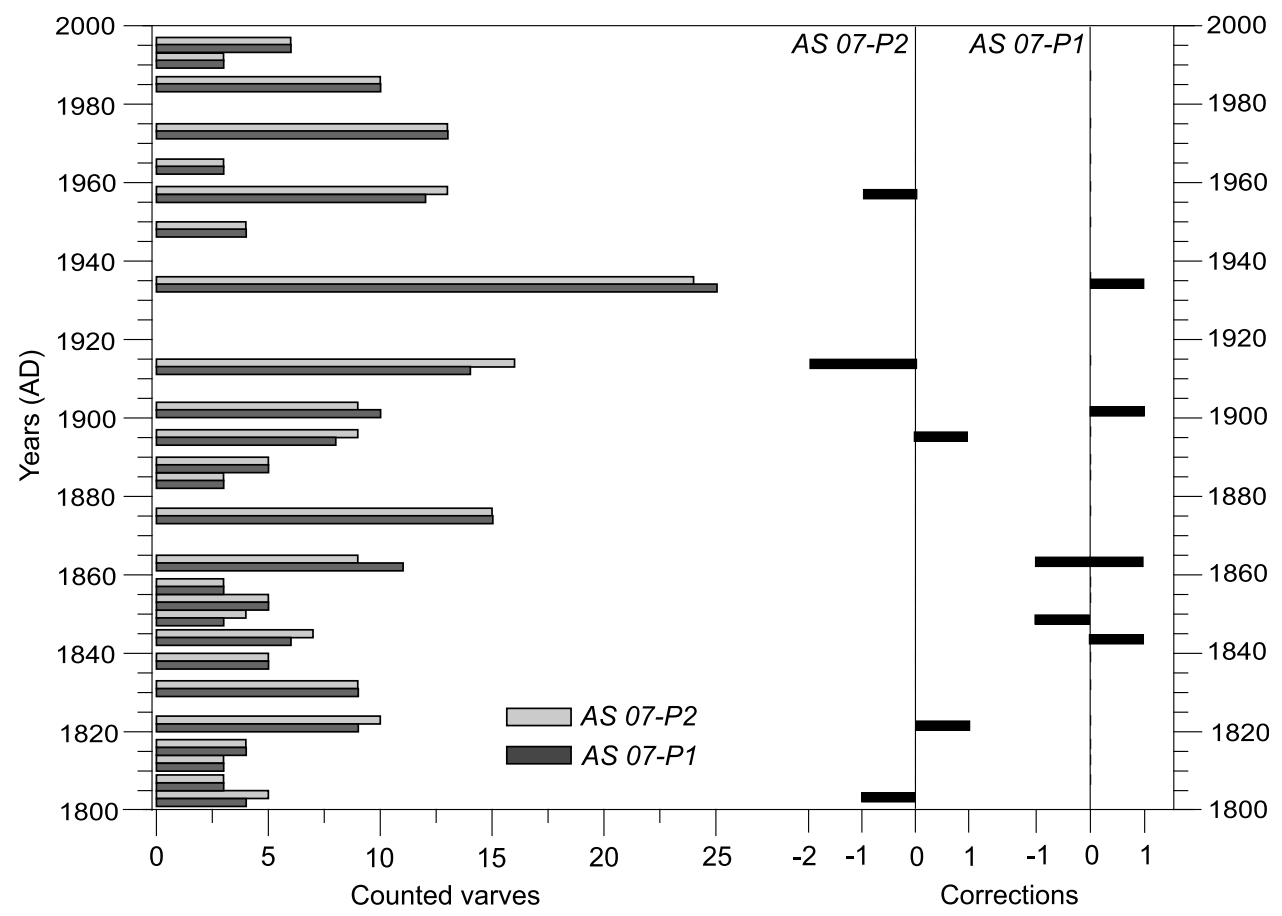

Figure 3. Comparison of varve chronologies for AS 07-P1 and AS 07-P2. Varves counted between two marker layers and corrections made for the composite chronology.

endogenic calcite precipitation is mainly induced through (1) biogenic assimilation of $\mathrm{CO}_{2}$ by photosynthesizing phytoplankton and (2) temperature increase [Kelts and Hs ̈̈, 1978; Stabel, 1986; Bluszcz et al., 2008], calcite layers form in the spring-summer season. Darker layers consist of detrital and amorphous organic material and littoral calcite, all internally redeposited through wave activity during fall and winter seasons. A clear change in varve microfacies is observed for the interval from 1960 to 1980. During this period two sublayers of a coarser $(5-7 \mu \mathrm{m})$ basal and a finer (2-4 $\mu \mathrm{m})$ upper calcite layer were deposited, each preceded by a diatom layer. This double-calcite-layer pattern is related to higher productivity during the lake's main eutrophication phase and has also been observed at Lake Zurich [Kelts and Hsü, 1978].

[15] In the first step, two independent varve chronologies were established for each core by microscopic calcite varve counting from 1999 back to 1545 (AS 07-P1) and 1800 (AS 07-P2). The disturbed sediment-water interface owing to the coring process prevented counting of the uppermost seven varves. Therefore, the resulting chronology was floating and had to be anchored to the absolute time scale using an exceptional detrital layer of known age (D2; Figure 2). Sediment trap studies close to the coring site of AS 07-P2 have proven the deposition of this layer in July 1993 [Alefs et al., 1996] after the breakup of an armor layer in the Ammer tributary Halbammer (see section 5.1). The deposition time of this layer is confirmed by a sediment core obtained from Lake Ammersee on 6 October 1993 (AS $T_{\max } 93$ ) by U. von Grafenstein, showing layer D2 on the top of the core. Some short intervals of poor varve preservation, comprising between 2 and 6 years, appear in 14.9\% of AS 07-P1 and in $22.5 \%$ of AS $07-\mathrm{P} 2$. These intervals were interpolated using the mean varve thickness of well-preserved adjacent sediment intervals $(2.2 \mathrm{~mm}$ for AS $07-\mathrm{P} 1$ and $2.6 \mathrm{~mm}$ for AS 07-P2).

[16] In the second step a composite chronology was established back to 1800 by combining counts of the best preserved parts of each chronology ("best-of" composite). This was achieved through comparison of varve counts separately for 26 intervals of about the same length precisely defined through distinct marker layers (Figure 3). Such detailed comparison allowed identification of even single missing varves in either of the cores and bridging of poorly preserved varve intervals in one core by using the varve count from the parallel core [Brauer et al., 2008].

[17] In the final step the resulting composite chronology was compared with historical Ammer flood observations from the city chronicle of Weilheim/Ammer [Alefs, 1997], indicating an overestimation of two varves in the interval from 1884 to 1912 . The entire varve chronology back to 1545 was then corrected for this bias. The resulting composite chronology differs less than $2 \%$ from a previous varve chronology for Lake Ammersee sediments reaching back to 1786 [Alefs, 1997].

\subsection{Detrital Layer Microfacies}

[18] Three main classes of detrital microfacies have been distinguished in the studied sediment interval: (1) graded layers, (2) silt/clay layers, and (3) matrix-supported layers (Figure 4). Thirty-four detrital layers in the parallel parts of both cores were studied and compared in detail for microfacies and layer thickness.

[19] 1. Graded layers are characterized by a normal grading from fine sand and coarse silt (average grain size of $30 \mu \mathrm{m})$ to clay $(<2 \mu \mathrm{m})$. A sharp lower boundary clearly segregates the basal part of the layer from the underlying sediment. Multiple grading and flame structures in the 

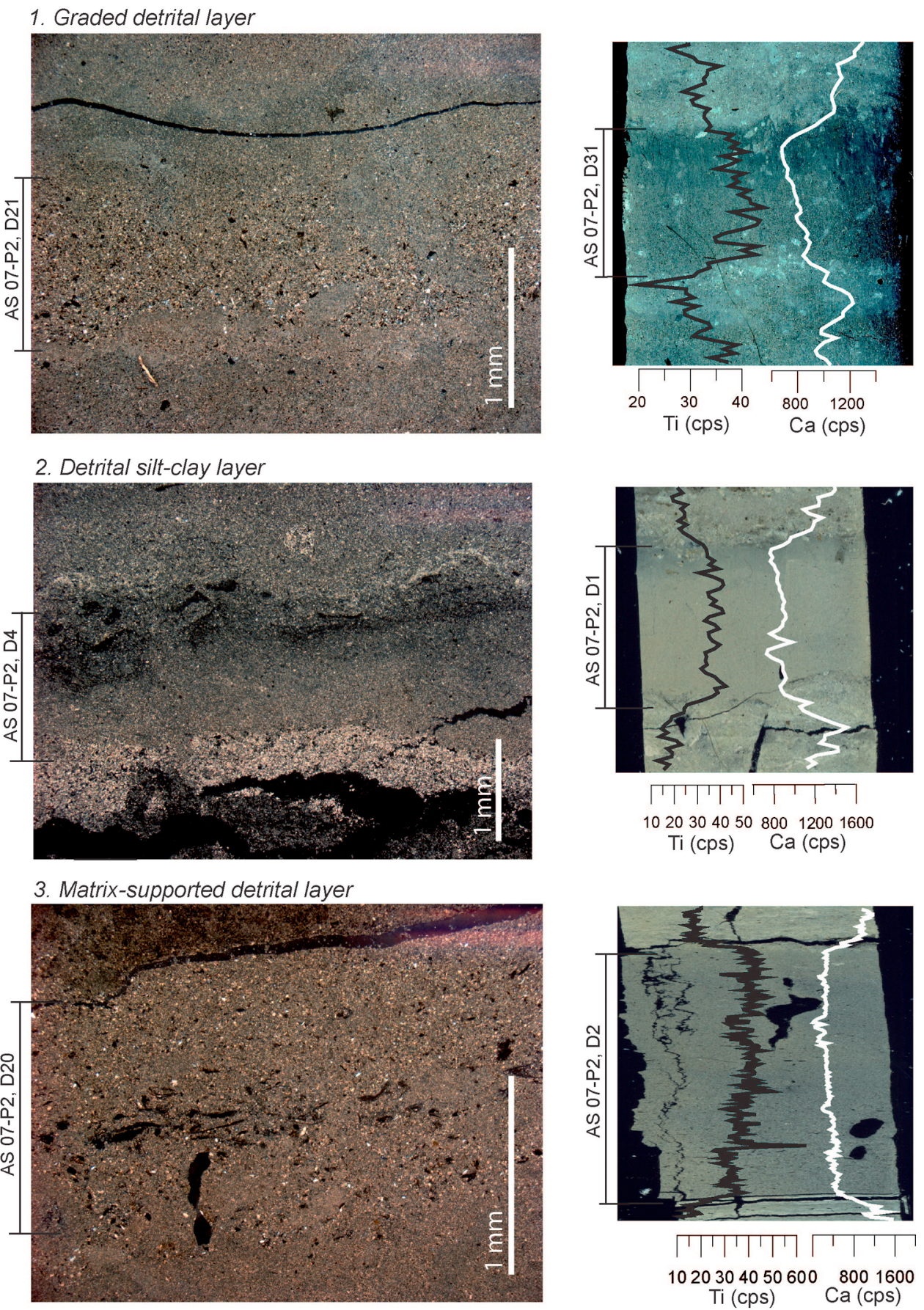

Figure 4. Polarized microscope photos $(25 \times)$ and thin section scans of detrital microfacies: (top) class 1: graded layers; (middle) class 2: silt/clay layers; and (bottom) class 3: matrix-supported layers. Detrital microfacies are confirmed by positive $\mathrm{Ti}$ and negative $\mathrm{Ca} \mu$-XRF excursions. Note that microscope and thin-section images are from different layers.

basal part appear within few layers of this type. Thirteen of 34 correlating detrital layers exhibit this microfacies in both cores. The thickest graded layer is $10.8 \mathrm{~mm}$ (Figures 4 and 5).

[20] 2. For silt-clay layers, there are no particular textural organization, except for a barely visible faint grading in a few cases, defines this layer type. The fine silt-clay detritus lacks the coarser material included in graded layers but shows the same elemental, isotopic, and mineralogical composition as the other detrital microfacies (see section 4.3). Four of 34 correlating detrital layers exhibit this layer type in both cores (Figures 4 and 5). The thickest layer of this type is $9.6 \mathrm{~mm}$.

[21] 3. Matrix-supported layers consist of predominantly fine sand to coarse silt detrital grains in a matrix of clots of endogenic calcite. Horizontally oriented plant remains and 


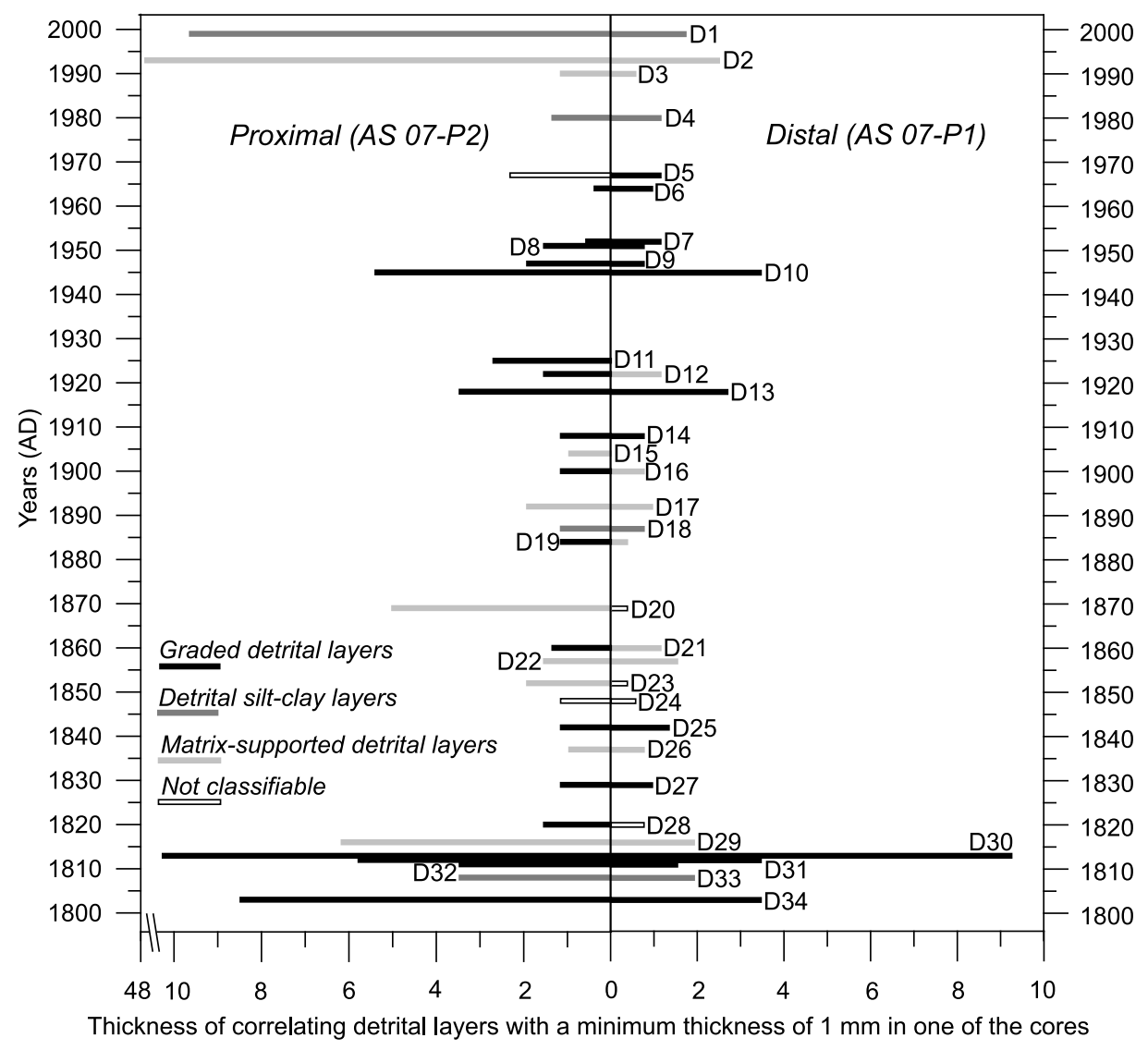

Figure 5. Thickness and microfacies for detrital layers thicker than $1 \mathrm{~mm}$ in one of the cores (AS 07-P1 and AS 07-P2) between 1800 and 1999 (time span covered by both cores).

littoral diatoms appear solely in this layer type. The textural organization shows weak grading in a few cases. Six of 34 correlating detrital layers are matrix-supported layers in both cores (Figures 4 and 5). The thickest matrix-supported layer is $47.1 \mathrm{~mm}(\mathrm{D} 2)$.

[22] Varve-to-varve correlation between both cores allowed identification of differences in microfacies for the same event of detrital matter flux into the lake basin and provided information on sediment transport processes within the lake. Four of 34 layers exhibit different microfacies in each core. These are graded layers in the proximal core AS 07-P2 that correlate with matrix-supported layers in the distal core AS 07-P1 (D12, D16, D19, D21). For one graded (D11) and one matrix-supported (D15) layer in the proximal core, no correlating layer was found in the distal core (Figure 5). In one case (D 11) this might be due to slight sediment distortions probably occurring during sample preparation, while the amount of detrital matter forming layer D15 at the proximal site was too low (very thin layer) to reach the distal core position. Microfacies types for four layers could not be unambiguously classified in one of the cores (Figure 5): two of these are matrix-supported layers in the proximal core (D20, D23), one is a graded layer in the proximal core (D28), and one is a graded layer in the distal core (D5). One layer was not classifiable in either core (D24). A likely explanation for these problems in microfacies classification is minor artifacts caused by the sample preparation procedure.
[23] The detrital layer thickness of all three detrital microfacies exhibits a distinct proximal-distal pattern (Figures 2 and 5). Consequently, the accumulated detrital layer thickness is higher by a factor of 2.6 in the proximal core. Thirty of 34 detrital layers are thicker in the proximal core AS 07-P2, as expected. The four exceptions are either equally thick (D22) or slightly thicker (D6, D7, D25) in the distal core (Figure 5). However, these differences in thickness measurements are not significant and are likely biased by sediment disturbances caused during sample preparation.

\subsection{Composition of Detrital Layers}

[24] Micro-XRF scanning provides high-resolution data on major element variations. Ti was selected as the indicator for detrital input since it is redox insensitive and clearly of terrigenous origin [Binder, 1999; Haug et al., 2001]. Positive correlations in cores AS 07-P1 and AS 07-P2 between $\mathrm{Ti}$ and $\mathrm{Fe}(r=0.87 / 0.90), \mathrm{K}(r=0.88 / 0.89), \mathrm{Si}(r=0.74 /$ $0.77)$, and $\mathrm{Al}(\mathrm{r}=0.55 / 0.60)$ indicate this element cluster to be of detrital origin. $\mathrm{Ca}$, in contrast, is strongly anticorrelated with $\mathrm{Ti}$ and exhibits a stronger anticorrelation in the proximal core AS 07-P2 $(r=-0.53 /-0.70)$. Confirming microfacies analyses, $\mu$-XRF profiles exhibit distinct positive $\mathrm{Ti}$ and negative $\mathrm{Ca}$ excursions for detrital layers (Figures 2, 4, and 6). Mg count rates are very low and thus do not exhibit variations for a reliable interpretation. XRD analyses reveal quartz, calcite, albite, and clinochlore as 


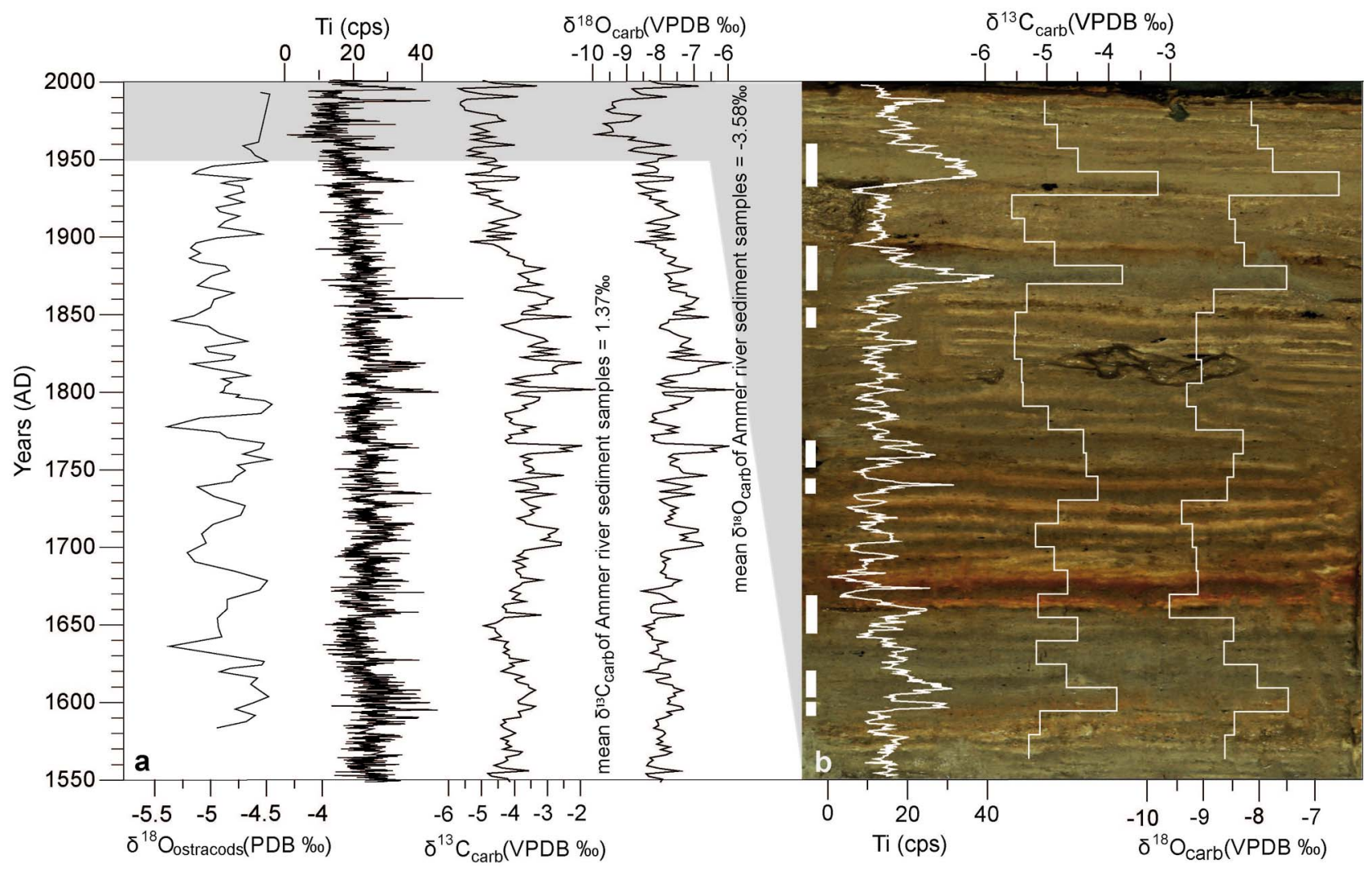

Figure 6. (a) $\delta^{18} \mathrm{O}_{\text {ostracods }}$ [von Grafenstein et al., 1992], Ti count rates (cps), and $\delta^{13} \mathrm{C}_{\text {carb }}$ and $\delta^{18} \mathrm{O}_{\text {carb }}$ (\%) data from core AS 07-P1. (b) Highlighted varve interval underlain by a core photo exhibiting detrital layers (white bars) with coinciding positive Ti (cps) excursions and heavier $\delta^{13} \mathrm{C}_{\text {carb }}$ and $\delta^{18} \mathrm{O}_{\text {carb }}$ values. Note the different resolution of $\mu$-XRF $(200 \mu \mathrm{m})$ and stable isotope data $(0.5 \mathrm{~cm})$.

mineral phases in all detrital microfacies. The very weak signal of dolomite is in agreement with the low $\mu$-XRF $\mathrm{Mg}$ count rates. This result differs from reports by Müller and Sigl [1977], who describe dolomite as a main mineral phase in surface sediments near the Ammer River mouth.

[25] Core AS 07-P1 $\delta^{18} \mathrm{O}_{\text {carb }}$ isotope values range between $-9.62 \%$ and $-5.71 \%$, with an average of $-7.67 \%$, while $\delta^{18} \mathrm{O}_{\text {carb }}$ isotope values from core AS 07-P2 range between $-9.30 \%$ and $-3.96 \%$, with an average of $-7.03 \%$. Core AS 07-P1 $\delta^{13} \mathrm{C}_{\text {carb }}$ isotope values range between $-5.69 \%$ and $-1.70 \%$, with an average of $-4.15 \%$, while $\delta^{13} \mathrm{C}_{\text {carb }}$ isotope values from core AS 07-P2 range between $-5.31 \%$ and $0.22 \%$, with an average of $-3.44 \%$ (Figure 6 ). For both cores a strong covariance between $\delta^{18} \mathrm{O}_{\text {carb }}$ and $\delta^{13} \mathrm{C}_{\text {carb }}$ is revealed (AS 07-P1, $r=0.91$; AS 07-P2, $r=$ 0.98). Covariance of $\delta^{18} \mathrm{O}$ and $\delta^{13} \mathrm{C}$ commonly indicates either a hydrologically closed lake system [Leng and Marshall, 2004] or detrital contamination [Mangili et al., 2010]. Since Lake Ammersee is a hydrologically open lake system [Alefs, 1997] and clearly heavier isotope peaks coincide with detrital microfacies, it is obvious that $\delta^{18} \mathrm{O}_{\text {carb }}$ and $\delta{ }^{13} \mathrm{C}_{\text {carb }}$ data are mainly controlled by detrital (carbonate) contamination and do not reflect climatic fluctuations as $\delta^{18} \mathrm{O}$ from benthic ostracods in Lake Ammersee [von Grafenstein et al., 1992, 1996, 1999] (Figure 6). This result is confirmed by isotope measurements of six samples of fine-grained detrital
Ammer riverbed material from three locations (Figure 1) indicating heavy isotope values between $-4.54 \%$ and $-3.29 \%$, with a mean of $-3.58 \%$, for $\delta^{18} \mathrm{O}_{\text {carb }}$ and between $1.04 \%$ and $1.70 \%$, with a mean of $1.37 \%$, for $\delta^{13} \mathrm{C}_{\text {carb }}$ (Figure 6). The wider isotope value range and heavier average and maximum isotope values suggest higher detrital contamination in the proximal core AS 07-P2. Sources of the detrital carbonates are probably outcrops of Cretaceous and Triassic carbonates and late moraine, flysch, and molasse formations in the Ammer catchment, all containing considerable amounts of calcite. The period of strongest eutrophication between 1960 and 1980 [Alefs, 1997; Alefs and Müller, 1999] is reflected by the more negative $\delta^{18} \mathrm{O}_{\text {carb }}$ values in the Lake Ammersee sediments (Figure 6).

\subsection{Seasonal Detrital Layers Versus Instrumental Data (1926-1999)}

[26] A comparison of the detrital layer record from the composite profile with instrumental daily runoff data from 1926 to 1999 proves that all detrital layers deposited during this time interval have been triggered by floods (Table 1) and confirms the microstratigraphically determined seasonality of flood layers. For 15 of 22 detrital layers the ascertained season has been determined exactly. Three detrital layers designated as "summer" layers correspond to May floods, two designated "spring" layers correspond to 
Table 1. Runoff and Precipitation Data for the 17 Highest River Ammer Flood Events (Daily Runoff $\geq 125 \mathrm{~m}^{3} / \mathrm{s}$ ), Date of Deposition, and Thickness of Detrital Layers From 1926 to 1999 and for Floods Below $125 \mathrm{~m}^{3} / \mathrm{s}$ Causing Detrital Layer Deposition ${ }^{\mathrm{a}}$

\begin{tabular}{|c|c|c|c|c|c|c|c|c|}
\hline Date of Flood Event & $\begin{array}{l}\text { Max. Daily } \\
\text { Runoff During } \\
\text { Flood }\left(\mathrm{m}^{3} / \mathrm{s}\right)\end{array}$ & $\begin{array}{l}\text { Peak Runoff } \\
\text { During Flood } \\
\left(\mathrm{m}^{3} / \mathrm{s}\right)\end{array}$ & $\begin{array}{c}\text { Days With } \\
\geq 100 \mathrm{~m}^{3} / \mathrm{s} \\
\text { Daily Runoff } \\
\text { During Flood }\end{array}$ & $\begin{array}{l}\text { Max. } \\
\text { Precipitation } \\
\text { During Flood } \\
(\mathrm{mm} / \mathrm{d})\end{array}$ & $\begin{array}{l}\text { Precipitation } \\
\text { Total During } \\
\text { Flood (mm) }\end{array}$ & Category & $\begin{array}{c}\text { Year and Season } \\
\text { of Detrital } \\
\text { Layer } \\
\text { Deposition }\end{array}$ & $\begin{array}{l}\text { Detrital Layer } \\
\text { Thickness }(\mathrm{mm})\end{array}$ \\
\hline \multicolumn{9}{|c|}{ Highest River Ammer Flood Events } \\
\hline 21/22/23.5.1999 & 534.64 & 649.4 & 3 & 138.5 & 186.4 & 3 & Summer 1999 & 1.74 \\
\hline 19/20.7.1981 & 174 & 238.9 & 2 & 69.7 & 156.6 & 3 & Summer 1981 & 1.16 \\
\hline 17/18/19.6.1979 & 257 & 291 & 3 & 39.1 & 116 & 3 & Spring 1979 & 0.39 \\
\hline 2.6 .1976 & 161 & 216.3 & 1 & 81.6 & 120 & 3 & Summer 1976 & 0.39 \\
\hline 10.8.1970 & 261.941 & 338 & 1 & 91.2 & 137.5 & 3 & & \\
\hline 23.7.1966 & 130.991 & 258 & 2 & 46.2 & 70.7 & 2 & & \\
\hline 11.6.1965 & 224.953 & 273 & 2 & 72.2 & 119 & 3 & Summer 1965 & 0.96 \\
\hline 14.6.1959 & 136.971 & 155 & 1 & 47.9 & 81.6 & 2 & Spring 1959* & $0.58^{*}$ \\
\hline $8 / 9 / 10.7 .1954$ & 169.993 & 208 & 4 & 51.6 & 155.7 & 3 & Summer 1954 & 1.16 \\
\hline 22/23.5. 1949 & 203.973 & 222 & 3 & 74 & 164.2 & 3 & Summer 1949 & 0.77 \\
\hline 7/8/9.7.1946 & 261.261 & 461 & 3 & 69.2 & 188.8 & 3 & Summer 1946 & 3.47 \\
\hline 24.11.1944 & 158.972 & 197 & 1 & 19.5 & 35.2 & 3 & & \\
\hline $30 / 31.5 .1940$ & 389.906 & 400 & 3 & 97.7 & 209.5 & 3 & $\begin{array}{l}\text { Disturbed } \\
\text { sediments }\end{array}$ & $\begin{array}{l}\text { Disturbed } \\
\text { sediments }\end{array}$ \\
\hline 24.8.1937 & 139.371 & 163 & 1 & 49.1 & 84 & 2 & Summer 1937* & $0.58^{*}$ \\
\hline 10.7.1932 & 129.976 & 216 & 1 & 47.1 & 78.5 & 2 & Summer 1932 & 0.58 \\
\hline 15.5.1930 & 149.974 & 216 & 1 & 63.8 & 92.5 & 2 & Summer 1930 & 0.58 \\
\hline 20.8 .1929 & 146.974 & 167 & 1 & 74.2 & 105.5 & 2 & $\begin{array}{l}\text { Disturbed } \\
\text { sediments }\end{array}$ & $\begin{array}{l}\text { Disturbed } \\
\text { sediments }\end{array}$ \\
\hline \multicolumn{9}{|c|}{ Floods Below $125 \mathrm{~m}^{3} / \mathrm{s}$} \\
\hline 11.7.1993 & 103.096 & & 1 & 63.9 & 81.4 & 1 & Summer 1993 & 2.51 \\
\hline 15.2.1990 & 105.507 & 153.7 & 1 & 54.4 & 72.8 & 1 & Spring 1990 & 0.58 \\
\hline 21.3 .1978 & 70.5 & 130.4 & 0 & 29.6 & 39.4 & 0 & Spring 1978* & $0.77 *$ \\
\hline 22.11 .1972 & 39.8 & 58.5 & 0 & 40.1 & 53.9 & 0 & Fall 1972 & 0.58 \\
\hline 2.10 .1968 & 89.185 & 139 & 0 & 48.9 & 63.6 & 0 & Fall 1968 & 1.16 \\
\hline 2.12 .1952 & 45.596 & 52.6 & 0 & 13.2 & 24 & 0 & Winter 1952 & 0.77 \\
\hline 2.9 .1950 & 55.5 & 134 & 0 & 28.9 & 40.5 & 0 & Fall $1950^{*}$ & $0.77 *$ \\
\hline 24.11 .1947 & 44.596 & 104 & 0 & 11.2 & 14.4 & 0 & Fall 1947 & 0.39 \\
\hline 1.9 .1938 & 70.999 & & 0 & 35.8 & 45.6 & 0 & Fall 1938 & 0.39 \\
\hline 5.2 .1935 & 49.5 & 57 & 0 & 11.3 & 30.2 & 0 & Spring $1935^{*}$ & $0.58^{*}$ \\
\hline
\end{tabular}

${ }^{\mathrm{a}}$ Categories for flood events are $(3) \geq 150 \mathrm{~m}^{3} / \mathrm{s},(2) \geq 125 \mathrm{~m}^{3} / \mathrm{s},(1) \geq 100 \mathrm{~m}^{3} / \mathrm{s}$, and $(0)<100 \mathrm{~m}^{3} / \mathrm{s}$. Detrital layer thickness is from core AS $07-\mathrm{P} 1$ except where indicated by an asterisk, which denotes that it is from core AS 07-P2. Precipitation sums for flood events were calculated by adding the daily precipitation during and 2 days before daily runoff $\geq 100 \mathrm{~m}^{3} / \mathrm{s}$.

February floods, and two other designated spring layers reflect a June flood (Table 1). These uncertainties are due to the criteria used for determining the season of a detrital layer. A summer layer is defined as a layer deposited after initial calcite formation in the lake. Since calcite formation in warm years may start as early as March or April, a detrital layer triggered by a May flood may appear as a summer layer in the microstratigraphic record. Flood layers deposited directly before the onset of calcite precipitation are considered spring layers, so that a February flood layer may appear as a spring layer. Interpretation of June floods as spring layers can be explained by microerosion that could have displaced the thin layer of precipitated calcite on the lake floor. Having taken this information into consideration, we are confident that we have obtained a reasonably precise seasonal flood layer record.

[27] For evaluation of the relation between flood layers and high-magnitude floods, the 38 strongest floods during the instrumental period were subdivided into three classes, with a mean daily runoff $(3) \geq 150 \mathrm{~m}^{3} / \mathrm{s}(n=11),(2) \geq 125 \mathrm{~m}^{3} / \mathrm{s}$ $(n=17)$, and $(1) \geq 100 \mathrm{~m}^{3} / \mathrm{s}(n=38)$. (Hereafter all daily runoff information refer to mean daily runoff.) The recurrence time of floods in class 3 is 6.7 years, while it is 4.4 and 1.9 years for classes 2 and 1, respectively. Except for the November 1944 flood, all floods with a daily runoff $\geq 125 \mathrm{~m}^{3} / \mathrm{s}$ occurred between May and August, indicating spring and summer to be major flood seasons (Figure 7). This pattern does not change much when all floods $\geq 100 \mathrm{~m}^{3} / \mathrm{s}$ [Bayerisches Landesamt für Umwelt, 2007] are considered (Figure 7). As confirmed by previously published data, floods of this magnitude [Ludwig et al., 2003], monthly precipitation (Meteorological Observatory Hohenpeißenberg), and seasonality of detrital layers all show a distinct maximum for spring and summer. For 8 of the 11 floods (73\%) with a daily runoff $\geq 150 \mathrm{~m}^{3} / \mathrm{s}$ and 12 of the 17 floods $(71 \%)$ with a daily runoff $\geq 125 \mathrm{~m}^{3} / \mathrm{s}$, corresponding spring-summer detrital layers have been found in the sediment record, respectively (Table 1 and Figure 8 ). Below $125 \mathrm{~m}^{3} / \mathrm{s}$ daily runoff the number of floods leading to detrital layer deposition clearly decreases. Only 2 of 21 floods with a daily runoff between 100 and $125 \mathrm{~m}^{3} / \mathrm{s}$ are reflected in the sediment record (Table 1). This suggests that a daily runoff of approximately $125 \mathrm{~m}^{3} / \mathrm{s}$ represents a threshold below which the deposition of a flood layer becomes less likely. The apparent lack of a relationship between flood magnitude and flood layer thickness (Figure 8) suggests complex nonlinearities in the erosion-transport-deposition process cascade [e.g., Lamb and Mohrig, 2009] that require further investigation.

[28] Such problems might also explain the lack of detrital layers corresponding to the July 1966 and August 1970 floods with $\geq 125 \mathrm{~m}^{3} / \mathrm{s}$ daily runoff. Probably, internal lake currents led to an inhomogeneous distribution of detrital 


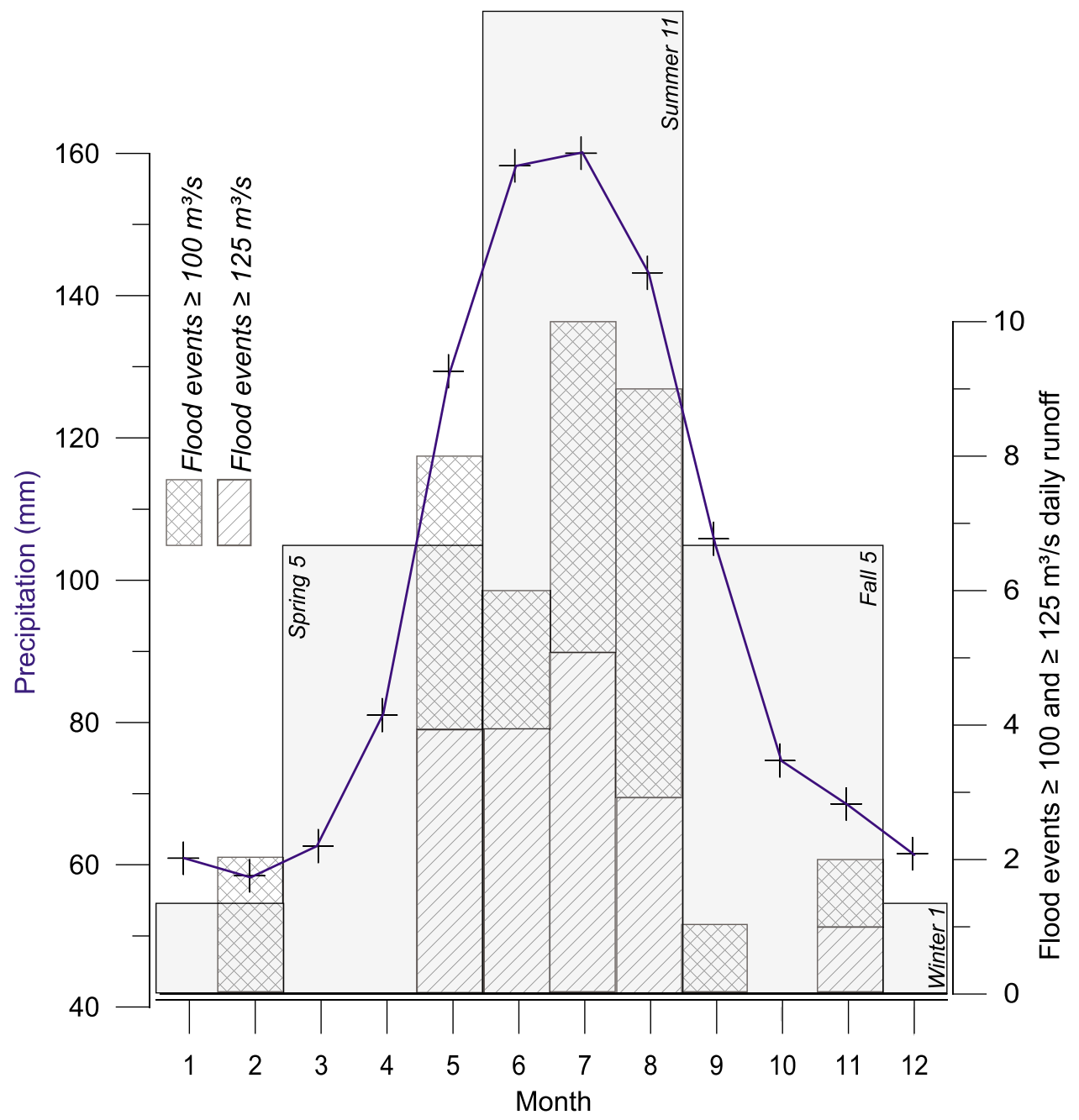

Figure 7. Seasonal distribution of detrital layers in the composite profile, monthly distribution of River Ammer flood events with daily runoff $\geq 100 \mathrm{~m}^{3} / \mathrm{s}(n=38)$ and $\geq 125 \mathrm{~m}^{3} / \mathrm{s}(n=17)$, and monthly precipitation distribution measured at the Meteorological Observatory Hohenpeißenberg approximately $20 \mathrm{~km}$ southwest of Lake Ammersee (solid blue line) within 1926 and 1999.

material on the lake floor, resulting in a lack of deposition at the coring sites. This can only be verified by a denser net of surface cores allowing an improved spatial view of the distribution of detrital layers on the lake floor. Two other spring-summer floods (August 1929, May 1940) that are not recorded in the sediment are likely missed because of sediment disturbances in the relevant core sections. The November 1944 flood likely is not recorded because after 3 weeks of daily surface temperatures below $0^{\circ} \mathrm{C}$ (Meteorological Observatory Hohenpeißenberg), the soil surface was frozen during the time of the flood triggering rainfall on 22-23 November, impeding soil erosion in the catchment and detrital matter flux into the lake.

[29] Besides the possibility of lacking detrital layers for some floods $\geq 125 \mathrm{~m}^{3} / \mathrm{s}$, also 10 floods below $125 \mathrm{~m}^{3} / \mathrm{s}$ led to the deposition of a detrital layer. However, six of these layers are related to fall-winter floods, which are not considered in our spring-summer flood time series. The production of fall flood layers during lower magnitude floods might be explained by possible sediment redistribution processes in the lake triggered by enhanced wave activity in fall. Additionally, two spring-summer layers are triggered by floods with $103 \mathrm{~m}^{3} / \mathrm{s}$ (thick layer D2) and $106 \mathrm{~m}^{3} / \mathrm{s}$ daily runoff, which is close to the defined threshold value of $125 \mathrm{~m}^{3} / \mathrm{s}$ daily runoff. That leaves two spring layers triggered by floods with clearly below $125 \mathrm{~m}^{3} / \mathrm{s}$ daily runoff, which are present only in the proximal core (Table 1).

[30] In conclusion, the detrital layer record in Lake Ammersee represents a time series of spring-summer floods with $\geq 125 \mathrm{~m}^{3} / \mathrm{s}$ daily runoff. Four spring-summer floods of this magnitude are not detected in the sediment record (two due to sediment disturbances), while four flood layers are related to spring-summer floods below this threshold (two rather close to the threshold of $125 \mathrm{~m}^{3} / \mathrm{s}$ daily runoff) (Table 1 ).

\subsection{Detrital Layer Frequency and Seasonal Distribution (1545-1999)}

[31] To establish a long flood time series back to 1545 , only detrital layers occurring in core AS 07-P1 were considered, because core AS 07-P2 reaches no farther back in 


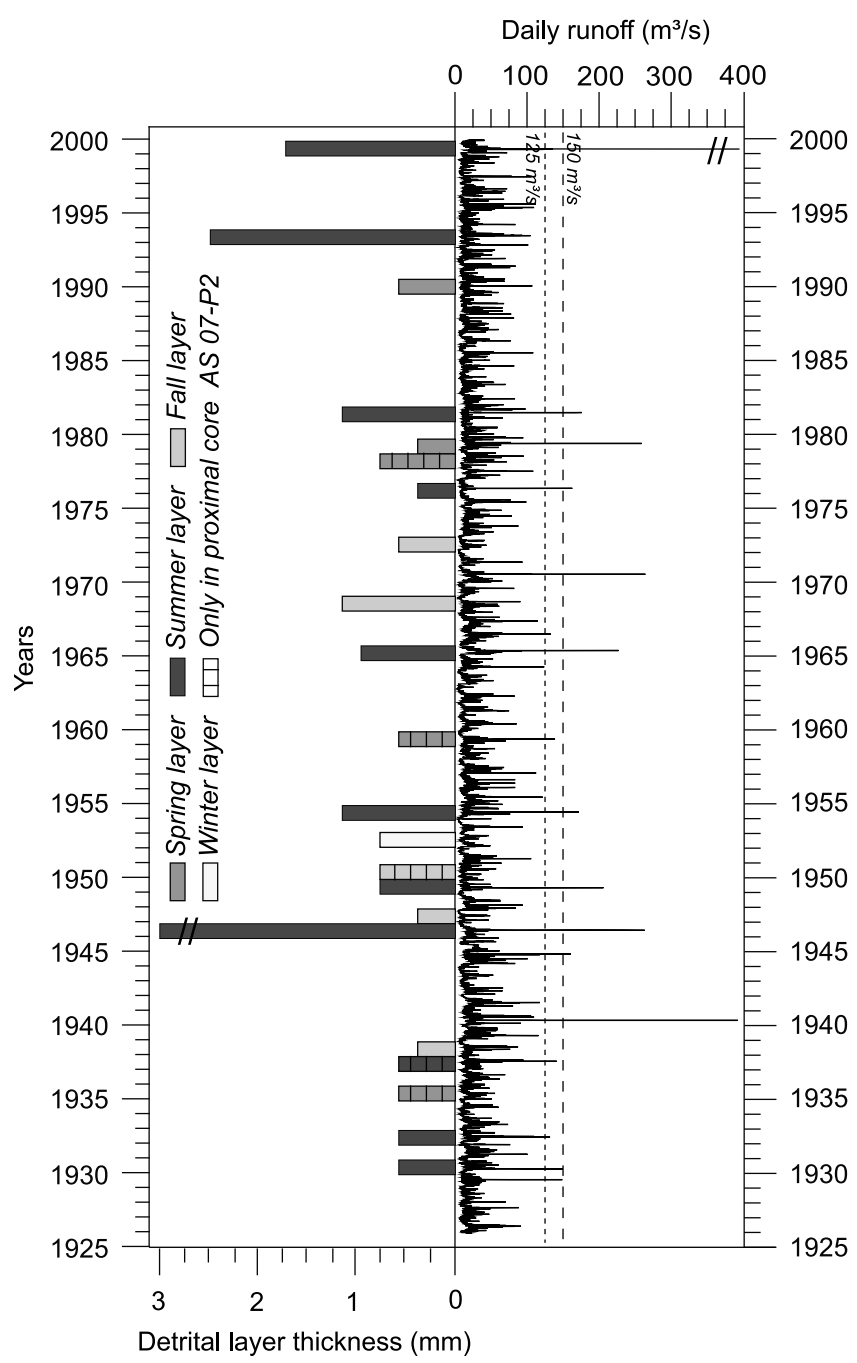

Figure 8. Daily River Ammer runoff $\left(\mathrm{m}^{3} / \mathrm{s}\right)$ and seasonal detrital layer thickness (mm) from 1926 to 1999. Detrital layer thickness is from core AS 07-P1 except when layers occur only in the proximal core AS 07-P2.

time than 1800. A total of 24 spring and 51 summer flood layers have been identified during this period. The average layer thickness is higher in summer $(1.24 \mathrm{~mm})$ than in spring
$(0.79 \mathrm{~mm})$. Frequency distributions of spring-summer flood layers exhibit distinct maxima of summer and minor maxima of spring layers between 1545 and 1590 , between 1650 and 1730, and between 1800 and 1840 (see Figure 12). The 12 fall $(0.70 \mathrm{~mm}), 5$ winter $(0.62 \mathrm{~mm})$, and 5 not seasonally definable layers in AS 07-P1 do not exhibit a clear distribution pattern.

[32] Detailed microstratigraphic comparison of both sediment cores for the calibration period has shown that four detrital spring-summer layers $(1978,1959,1937,1935)$ found in the proximal core are not detected in the distal core located $6.2 \mathrm{~km}$ from the Ammer River mouth and $1.8 \mathrm{~km}$ away for core AS 07-P2 (Table 1). Consequently, we have to expect a further underestimation of floods in this core, which might affect the frequency distribution in the case that the unrecorded floods are clustered in periods of low flood layer frequency. Since the identified missing spring-summer layers in AS 07-P1 during the calibration period are randomly distributed (Table 1), we are, however, confident that additional missing layers in the distal core do not significantly affect general trends in flood layer distribution.

\subsection{Detrital Layers Versus Weather Regime Data}

[33] To evaluate large-scale atmospheric circulation effects on River Ammer runoff, the 17 strongest River Ammer flood events (daily runoff $\geq 125 \mathrm{~m}^{3} / \mathrm{s}$ ) measured at gauge Weilheim [Bayerisches Landesamt für Umwelt, 2007] were compared with the occurrence of weather regimes over Europe from 1926 to 1999 (time covered by River Ammer runoff and weather regime data) using the weather regime (Großwetterlagen) catalog of Gerstengarbe and Werner [2005]. This catalog deciphers the daily occurrence of 30 characteristic weather regimes over Europe starting in 1881. The temporal offset between weather regime and river runoff was corrected using precipitation data from the Meteorological Observatory Hohenpeißenberg $20 \mathrm{~km}$ southwest of Lake Ammersee. Five weather regimes can be attributed to more than 1 of the highest 17 flood events. Three floods were each caused by Cyclonic Westerly (WZ) and High Over the British Isles (HB) weather regimes. Two floods occurred during Cyclonic Northwesterly (NWZ), Zonal Ridge Across Central Europe (BM), and Cyclonic Northeasterly (NEZ) weather regimes (Figures 9 and 10). The remaining five floods $\geq 125 \mathrm{~m}^{3} / \mathrm{s}$ are related to Anticyclonic Westerly (WA), Trough Over Central

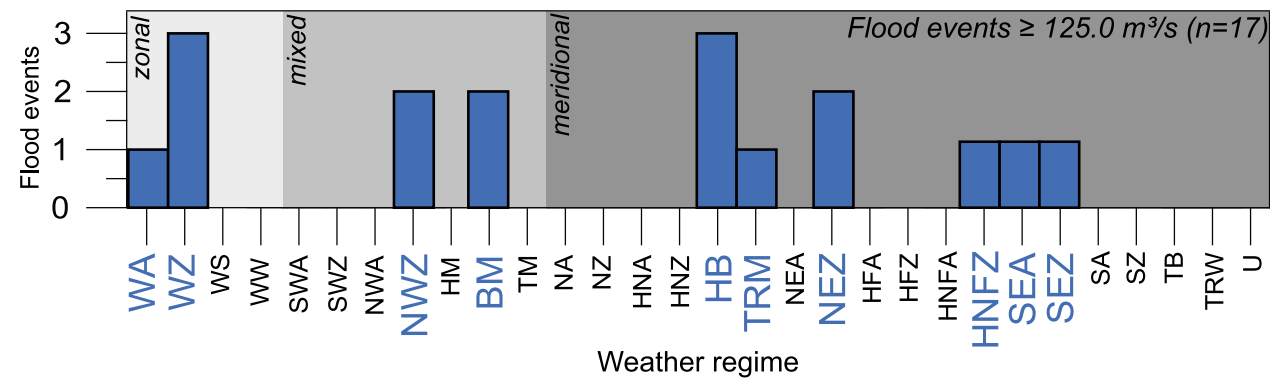

Figure 9. Weather regimes triggering the 17 highest River Ammer flood events (daily runoff, $\geq 125 \mathrm{~m}^{3} / \mathrm{s}$ ) between 1926 and 1999. BM, Zonal Ridge Across Central Europe; HB, High Over the British Isles; HNFZ, High Scandinavia-Iceland/Trough Central Europe; NEZ, Cyclonic Northeasterly; NWZ, Cyclonic Northwesterly; SEA, Anticyclonic Southeasterly; SEZ, Cyclonic Southeasterly; TRM, Trough Over Central Europe; WA, Anticyclonic Westerly; WZ, Cyclonic Westerly. 


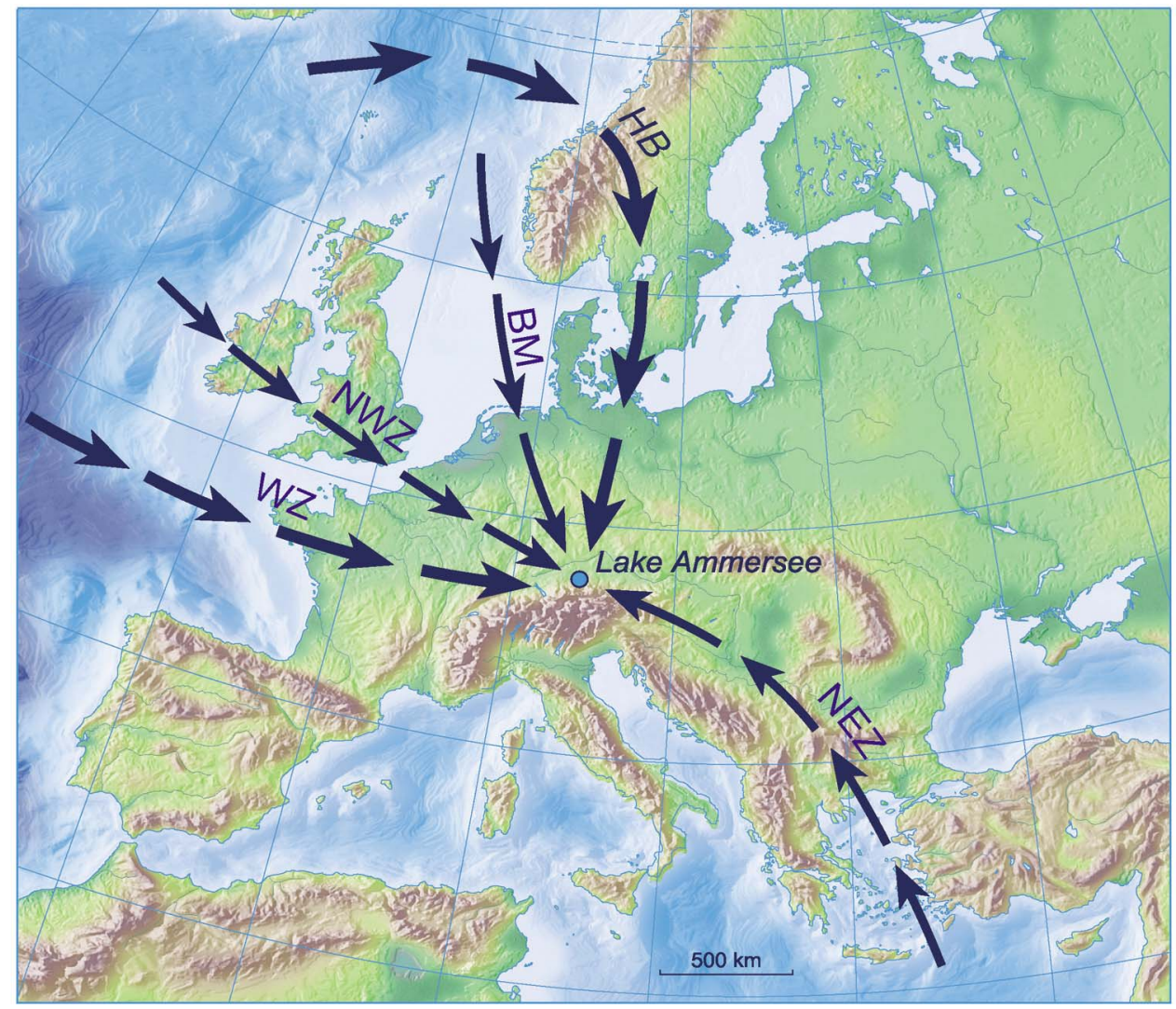

Figure 10. Expected pathway of cyclones during the main flood-prone weather regimes at Lake Ammersee: BM, HB, NEZ, NWZ, and WZ.

Europe (TRM), High Scandinavia-Iceland/Trough Central Europe (HNFZ), Anticyclonic Southeasterly (SEA), and Cyclonic Southeasterly (SEZ) weather regimes (Figure 9).

[34] The summer and annual occurrences of these floodprone weather regimes were compared with the detrital layer distribution in the longer core AS 07-P1 between 1881 and 1999 (time span covered by varve and weather regime data). Particularly, annual frequencies of flood-prone weather regimes indicate similar trends as the detrital layer distribution (Figure 11). The weaker agreement between summer flood-prone weather regimes and detrital layers might be due to difficulties regarding the seasonal segmentation of detrital layers (section 4.4). The link between flood-prone weather regimes and detrital layers seems weakened between 1920 and 1924, when additional detrital sediments enter the lake during construction work in the Ammer catchment for river channelization (Figure 11).

\section{Discussion}

\subsection{Depositional Processes of Detrital Layers}

[35] All three observed detrital microfacies types can be interpreted in terms of various depositional processes.

[36] 1. Grading, as well as abrasion and flame structures in the basal part of some layers, points to the deposition of hyperpycnal underflows [Mangili et al., 2005] as graded layers. Because of the amount of suspended matter and water temperature, the inflowing water-sediment suspension is of a higher density than the surrounding water body and moves as a density current along the lake floor [Sturm and
Matter, 1978]. During the spread within the lake basin the density difference between the water body and the turbidity current diminishes, leading to a reduced transport capacity and, consequently, successively finer grain sizes [Siegenthaler and Sturm, 1989]. This is reflected by grading and the proximal-distal pattern of detrital layer thickness in Lake Ammersee (Figures 4 and 5).

[37] 2. Silt-clay layers may form when fine silt and clay detrital material is transported into the lake by low-density currents. After entering the lake the detrital grains are distributed in the water column as over- or interflow, owing to the density of the inflowing current and that of the surrounding water body [Sturm and Matter, 1978; Mangili et al., 2005]. As reflected in the barely visible faint grading in some of these layers, the fine-grained material falls out of the water column and deposits within a few days on the lake bottom [Siegenthaler and Sturm, 1989]. Alternatively, this layer type might reflect distal deposits of high-density currents from which the coarser fraction has already been deposited [Mangili et al., 2005].

[38] 3. Various detrital and reworked sediment components, such as littoral calcite and diatom frustules and plant remains well mixed within the sediment matrix, form matrixsupported layers that are commonly thought to reflect major slope failures or debris flows. Correlation of the two studied cores, however, exhibits four matrix-supported layers in core AS $07-\mathrm{P} 1$ as distal deposits of graded layers. This confirms deposition after runoff events induced by underflows that have eroded material in the littoral zone of the lake. A special case is the thick matrix-supported layer D2. 


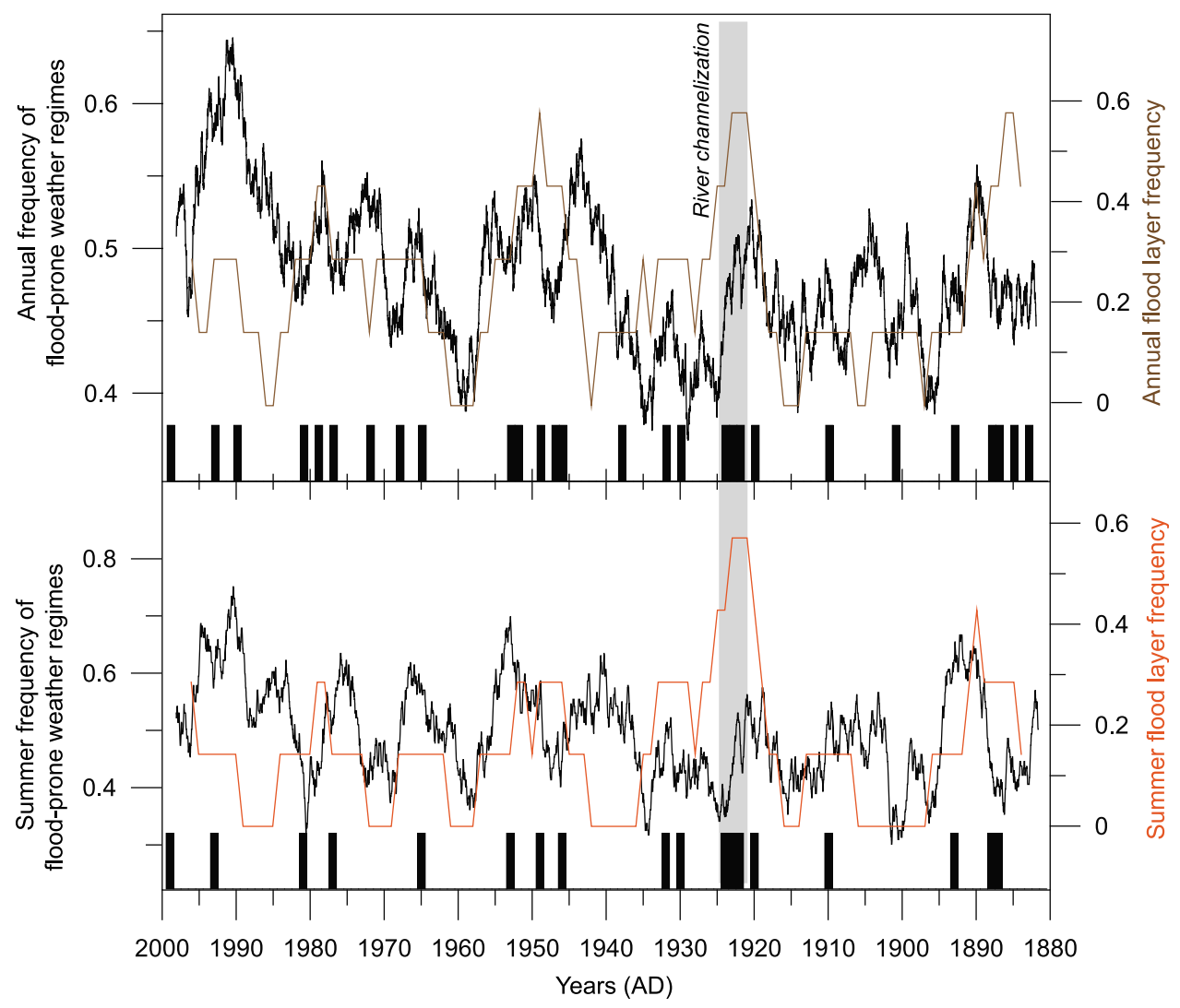

Figure 11. Summer and annual flood layer frequencies in core AS 07-P1 between 1881 and 1999 on a 7 year running mean and frequencies of flood-prone weather regimes (WA, WZ, NWZ, BM, HB, TRM, NEZ, HNFZ, SEA, SEZ) on a 249 and 999 point running mean, respectively. Detrital layers are marked by filled bars. The different smoothing of the individual data sets was chosen to obtain a similar running mean with respect to the resolution of the records. The period of River Ammer channelization is shaded.

The processes triggering the deposition of this layer in summer 1993 are well documented by (1) observations made by the Weilheim water authorities in the lake catchment, (2) sediment trap data obtained near the location of our core AS 07-P2 [Alefs, 1997], and (3) a sediment core obtained in October 1993. On 17 July 1993 a short (1.5 h) but intense local precipitation event $(100 \mathrm{~mm})$ caused a flood in the Ammer tributary Halbammer. This caused a breakup of the armor layer near the village Unternogg, in close proximity to the confluence of both rivers (Figure 1), causing an incision of the riverbed of some meters and the collapse of a Halbammer bridge (WasserwirtschaftsamtWeilheim, personal communication, 2008).

[39] In conclusion, microfacies analyses combined with instrumental runoff data from 1926 to 1999 (Table 1) prove that detrital layers in the Lake Ammersee sediments represent flood deposits [Sturm and Matter, 1978; Siegenthaler and Sturm, 1989] of the River Ammer. Alternative triggering mechanisms that are not directly related to floods [Mangili et al., 2005] are unlikely. No indications for debris flow deposits as observed in Lake Mondsee [Swierczynski et al., 2009] were found in the studied sediment interval. The only observed trigger for detrital sediment flux into the lake basin not directly related to a flood is the construction work for channelizing the Ammer River from 1920 to 1924
[Alefs, 1997]. Increased erosion led to a generally higher detrital input, facilitating detrital layer deposition even during low-magnitude floods.

\subsection{Paleoclimatic Implications}

[40] Much of the current climate debate focuses on global temperature fluctuations. Less well constrained are the responses of the hydrological cycle and, particularly, of extreme flood events to changes in climate boundary conditions. In addition to high-resolution temperature reconstructions [von Grafenstein et al., 1996, 1999], the Lake Ammersee sediment profile has a large potential for establishing long flood time series at seasonal precision. Despite the remaining lack of knowledge regarding the entire cascade of processes from a flood to the deposition of a flood layer at a certain point in the lake basin, methodological improvements allowed us to establish a reliable spring-summer flood layer time series including an assessment of the uncertainties. We are confident that these data are sufficient to identify a distinct and apparently not stationary temporal pattern in the distribution of flood layers. Higher frequencies, particularly of summer floods, are observed for colder periods during the Little Ice Age. Similar observations have been made in historical flood time 


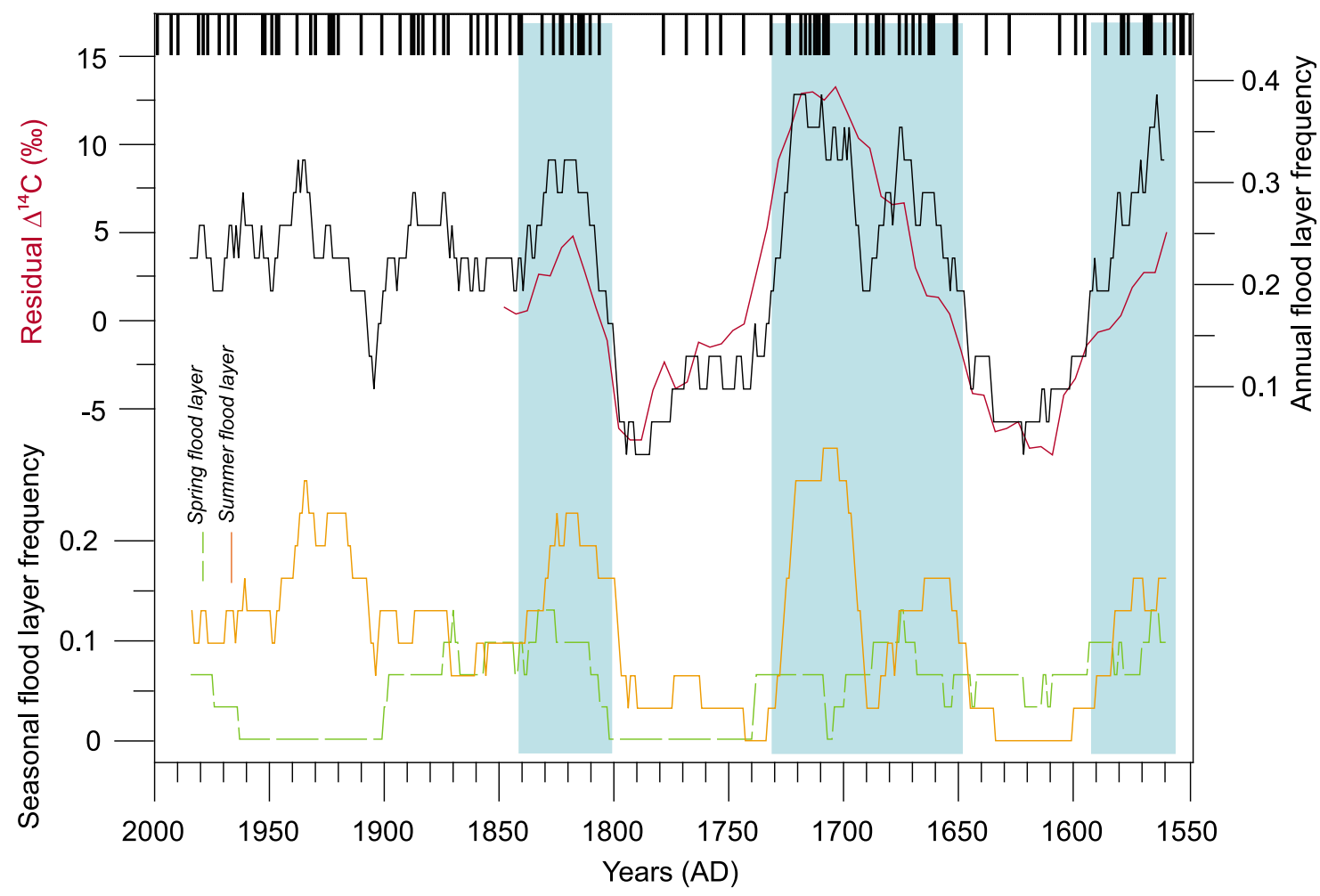

Figure 12. (top) Flood layers (solid bars) and annual flood layer frequency in core AS 07-P1 on a 31 year running mean (black line). Residual $\Delta^{14} \mathrm{C}$ on a 1000 year running mean (red line) [Reimer et al., 2004]. (bottom) Spring and summer flood layer frequencies on a 31 year running mean. Phases of lower solar activity during the Little Ice Age are highlighted by blue shading.

series of the River Main, located approximately $200 \mathrm{~km}$ north of Ammersee [Glaser and Stangl, 2004], pointing to a wider regional significance of this finding.

[41] The pattern of flood layer frequencies coincides well for the period from 1545 to 1845 with reconstructed variations of residual $\Delta^{14} \mathrm{C}$, commonly regarded as a proxy for solar activity [Usoskin et al., 2003; Solanki et al., 2004]. Particularly striking is the good agreement of maxima in summer and spring flood layers, with residual $\Delta^{14} \mathrm{C}$ maxima during the Little Ice Age between 1545 and 1590, between 1650 and 1730, and between 1800 and 1840 (Figure 12). The production of ${ }^{14} \mathrm{C}$ in the upper stratosphere is higher during times of lower solar activity because more cosmic radiation can reach the Earth's atmosphere, where it transforms ${ }^{14} \mathrm{~N}$ to ${ }^{14} \mathrm{C}$. Past atmospheric ${ }^{14} \mathrm{C}$ concentrations $\left(\Delta^{14} \mathrm{C}\right)$ have been reconstructed from tree rings and are expressed relative to the National Bureau of Standards oxalic acid standard activity in the $\Delta$ notation [Stuiver and Polach, 1977]. The residual $\Delta^{14} \mathrm{C}$ has been calculated from the IntCal04 $\Delta^{14} \mathrm{C}$ data set by removing a 1000 year running average from the record to reduce long-term geomagnetic field and reservoir effects. The residual $\Delta^{14} \mathrm{C}$ data do not extend to times younger than 1845 to exclude a bias through contamination by fossil-fuel burning [Reimer et al., 2004].

[42] The coincidence between decadal-scale solar activity minima and cooling [Waple et al., 2002], particularly in Europe during the Little Ice Age in the fifteenth to nineteenth centuries [Mann, 2002], suggests large-scale climatic responses to solar forcing. However, since the physical processes behind the solar-climate link are not yet fully understood, this remains a controversial discussion. Two hypotheses for possible amplifying mechanisms of the rather small variations in solar activity have been suggested [van Geel et al., 1999]. (1) Variations in UV irradiance alter stratospheric ozone production, leading to changes in total radiative forcing and atmospheric circulation [Haigh, 1994, 1996]. (2) Effects of solar magnetic variability on the Earth's cosmic ray shielding alter the production of cloud condensation nuclei and, consequently, cloud cover and precipitation [Svensmark and Friis-Christensen, 1997; Svensmark, 2000]. Although it is not straightforward to elaborate these feedback mechanisms in the climate system based on the Lake Ammersee flood record, the apparent link between high-magnitude floods and the occurrence of certain weather regimes in the Ammer catchment from 1881 to 1999 (Figure 11) provides motivation for further deliberations. Accepting that extreme floods are triggered by typical flood-prone weather regimes suggests that atmospheric circulation plays a major role in extreme flood initiation. Most of the high-magnitude River Ammer flood events in the observation period back to 1926 occurred in summer (Figure 7) during particular weather regimes (Figure 9). The increase in summer flood frequency during intervals of solar minima (Figure 12), therefore, points to a more frequent occurrence of these flood-prone weather regimes and, thus, to changes in large-scale atmospheric circulation patterns. The increase in spring floods during times of lower solar activity (Figure 12) might be additionally 
affected by stronger snowmelt due to an increase in winter snowfall [Beniston and Jungo, 2002; McEwen, 2006]. The coincidences between changes in flood frequency and both solar activity and the occurrence of flood-prone weather regimes might be a further argument in support of the hypothesis of solar variability effects on atmospheric circulation patterns. However, this hypothesis must be tested further by extending the flood layer record from Lake Ammersee farther back in time to cover also older intervals of reduced solar activity in the Holocene. Moreover, comparable flood records from other regions are required to obtain a better regional view of flood frequency patterns.

\section{Conclusions}

[43] All detrital layers in the Lake Ammersee sediment record have been proven to be flood deposits. Microscopic analyses of petrographic thin sections have identified spring and summer as the main seasons of flood layer deposition. On the basis of a precise varve chronology a 450 year flood layer time series has been contributing to a better understanding of the effects of changing climatic boundary conditions on flood frequency. This highlights the potential of varved lake sediments as promising archives for establishing even longer flood records.

[44] However, evaluating sediment archives necessitates considering the inherent data characteristics. On the one hand, sediment data cannot provide the same precision as instrumental or historical hydrological data in terms of time control, time resolution, and process quantification. On the other hand, only sediment archives reach far enough back in time to provide long-term information that cover up to several climatic cycles including periods without any human interference on landscape evolution. These differences between instrumental and geological data obviously require different analytical approaches. It is a challenging task to link both approaches by bridging the different time concepts. The first step in this respect is to improve the time resolution of geological records by using annually laminated sediments.

[45] In addition to the time scale issue, the complex processes involved in the deposition and preservation of a sediment archive must be better understood. Linking the Lake Ammersee flood layer record with instrumental Ammer flood time series has allowed, for the first time, definition of an approximate threshold in spring-summer flood magnitude making the deposition of a flood layer likely. Moreover, we were able to assess the degree of "completeness" of the flood layer record, that is, to identify floods for which no corresponding flood layer has been found. The resulting number of flood layers was sufficient to determine changes in frequency trends of spring and summer floods representing the main flood seasons in the region. These frequency patterns were compared with proxy data on solar activity revealing an intriguing coincidence between periods of reduced solar irradiance and increased flood frequency. The additional observation that strong springsummer floods correspond to the frequency of particular flood-prone weather regimes gives rise to speculations about possible effects of solar variability on midlatitude atmospheric dynamics.

[46] This study is a first step in developing varved lake sediments as flood records at, for geological archives, unprecedented seasonal resolution. It particularly highlights the great potential of this approach but, at the same time, clearly points out the remaining problems in interpretation that must be solved. Future work must aim at a better understanding of the processes controlling flood-triggered detrital matter erosion, transport, and deposition.

[47] Acknowledgments. This study is a contribution to the Helmholtz TERENO research project and the Helmholtz climate initiative REKLIM. The Wasserwirtschaftsamt Weilheim (WWA-WM) and the Bayerisches Landesamt für Umwelt (LfU) are acknowledged for providing River Ammer runoff data. Precipitation and temperature data from the Meteorological Observatory Hohenpeißenberg was supplied by the Deutscher Wetterdienst (DWD). We would like to thank D. Berger and G. Arnold (GFZ, Potsdam) for preparing high-quality thin sections, J. Zimmermann for his help with stable isotope measurements, and R. Niederreiter (UWITEC) for his support during sediment coring. A. Hendrich helped with the layout of figures. Flood layer data files are available at http://doi.pangaea. de/10.1594/PANGAEA.746240.

\section{References}

Alefs, J. (1997), Feinstratigraphie und Diatomeensukzession in den Profundalsedimenten des Ammersees und Starnberger Sees (Oberbayern), $\mathrm{Ph} . \mathrm{D}$. dissertation, Fak. für Chem., Biol. und Geowiss. der Tech. Univ. München, Munich, Germany.

Alefs, J., and J. Müller (1999), Differences in eutrophication dynamics of Ammersee and Starnberger See (southern Germany), reflected by the diatom succession in varve-dated sediments, J. Paleolimnol., 21(4), 395-407, doi:10.1023/A:1008098118867.

Alefs, J., J. Müller, and B. Lenhart (1996), Year to year changes of the diatom assemblage since 1958 in dated varves of a sediment core from Lake Ammersee (Bavaria), Limnologica, 26(1), 39-48.

Baker, V. R. (2006), Palaeoflood hydrology in a global context, Catena, 66(1-2), 161-168, doi:10.1016/j.catena.2005.11.016.

Bayerisches Landesamt für Wasserwirtschaft (2005), Seelitorale in Bayern: Ammersee, Untersuchung benthischer Diatomeen 2001, Mat. Bayerischen Landesamt Wasserwirsch., 120.

Bayerisches Landesamt für Umwelt (2007), Daily River Ammer runoff data from 1926 to 2005, report, Munich, Germany.

Beniston, M., and P. Jungo (2002), Shifts in the distributions of pressure, temperature and moisture and changes in the typical weather patterns in the Alpine region in response to the behavior of the North Atlantic Oscillation, Theor. Appl. Climatol., 71(1-2), 29-42, doi:10.1007/s704002-8206-7.

Binder, H. H. (1999), Lexikon der Chemischen Elemente, Das Periodensystem in Fakten, Zahlen und Daten, S. Hirzel, Stuttgart, Germany.

Bluszcz, P., E. P. Kirilova, A. F. Lotter, C. Ohlendorf, and B. Zolitschka (2008), Global radiation and onset of stratification as forcing factors of seasonal carbonate and organic matter flux dynamics in a hypertrophic hardwater lake (Sacrower See, northeastern Germany), Aquat. Geochem., 14(1), 73-98, doi:10.1007/s10498-008-9026-3.

Brauer, A. (2004), Annually laminated lake sediments and their palaeoclimatic relevance, in The Climate in Historical Times. Towards a Synthesis of Holocene Proxy Data and Climate Models, edited by H. Fischer et al., pp. 111-128, Springer, Berlin.

Brauer, A., and J. Casanova (2001), Chronology and depositional processes of the laminated sediment record from Lac d'Annecy, French Alps, J. Paleolimnol., 25(2), 163-177, doi:10.1023/A:1008136029735.

Brauer, A., C. Mangili, A. Moscariello, and A. Witt (2008), Palaeoclimatic implications from micro-facies data of a 5900 varve time series from the Piànico interglacial sediment record, southern Alps, Palaeogeogr. Palaeoclimatol., 259(2-3), 121-135, doi:10.1016/j.palaeo.2007.10.003.

Brauer, A., P. Dulski, C. Mangili, J. Mingram, and J. Liu (2009), The potential of varves in high-resolution paleolimnological studies, PAGESnews, 17(3), 96-98.

Dearing, J. A. (1991), Lake sediment records of erosional processes, Hydrobiologica, 214(1), 99-106, doi:10.1007/BF00050938.

Dearing, J. A., Y. Hu, P. Doody, P. A. James, and A. Brauer (2001), Preliminary reconstruction of sediment-source linkages from the past $6000 \mathrm{yr}$ at the Petit Lac d'Annecy, France, based on mineral magnetic data, J. Paleolimnol., 25(2), 245-248, doi:10.1023/A:1008186501993.

Gerstengarbe, F.-W., and P. C. Werner (2005), Katalog der Großwetterlagen Europas (1881-2004) nach Paul Hess und Helmut Brezowsky, 
verbesserte und ergänzte Auflage, Rep. Issue 6, Potsdam Inst. For Clim. Impact Res., Potsdam, Germany.

Glaser, R., and H. Stangl (2004), Climate and floods in Central Europe since AD 1000: Data, methods, results and consequences, Surv. Geophys., 25(5-6), 485-510, doi:10.1007/s10712-004-6201-y.

Haigh, J. D. (1994), The role of stratospheric ozone in modulating the solar radiative forcing of climate, Nature, 370(6490), 544-546, doi:10.1038/ $370544 \mathrm{a} 0$.

Haigh, J. D. (1996), The impact of solar variability on climate, Science, 272(5264), 981-984, doi:10.1126/science.272.5264.981.

Haug, G. H., K. A. Hughen, D. M. Sigman, L. C. Peterson, and U. Röhl (2001), Southward migration of the Intertropical Convergence Zone through the Holocene, Science, 293(5533), 1304-1308, doi:10.1126/ science. 1059725 .

Kelts, K., and K. Hsü (1978), Freshwater carbonate sedimentation, in Lakes: Chemistry, Geology, Physics, edited by A. Lerman, pp. 295-323, Springer, New York.

Knox, J. C. (1993), Large increases in flood magnitude in response to modest changes in climate, Nature, 361(6411), 430-432, doi:10.1038/ 361430a0.

Knox, J. C., and Z. W. Kundzewicz (1997), Extreme hydrological events, palaeo-information and climate change, Hydrol. Sci. J., 42(5), 765-779, doi: $10.1080 / 02626669709492071$.

Lamb, M. P., and D. Mohrig (2009), Do hyperpycnal-flow deposits record river-flood dynamics?, Geology, 37(12), 1067-1070, doi:10.1130/ G302826A.1

Leng, M. J., and J. D. Marshall (2004), Palaeoclimate interpretation of stable isotope data from lake sediment archives, Quat. Sci. Rev., 23(7-8), 811-831, doi:10.1016/j.quascirev.2003.06.012.

Lotter, A. F., and G. Lemcke (1999), Methods for preparing and counting biochemical varves, Boreas, 28(2), 243-252, doi:10.1111/j.1502-3885. 1999.tb00218.x.

Ludwig, R., S. Tascher, and W. Mauser (2003), Modelling floods in the Ammer catchment: Limitations and challenges with a coupled meteohydrological model approach, Hydrol. Earth Syst. Sci., 7(6), 833-847.

Mangelsdorf, J., and K. Zelinka (1973), Zur Hydrochemie der Ammer (Oberbayern) und ihrer Zuflüsse, Wasserwirtschaft, 63, 1-5.

Mangili, C., A. Brauer, A. Moscariello, and R. Naumann (2005), Microfacies of detrital event layers deposited in Quaternary varved lake sediments of the Piànico-Sèllere Basin (northern Italy), Sedimentology, 52(5), 927-943, doi:10.1111/j.1365-3091.2005.00717.x.

Mangili, C., A. Brauer, B. Plessen, P. Dulski, A. Moscariello, and R. Naumann (2010), Effects of detrital carbonate on stable oxygen and carbon isotope data from varved sediments of the interglacial Piànico palaeolake (southern Alps, Italy), J. Quat. Sci., 25(2), 135-145, doi:10.1002/jqs. 1282.

Mann, M. E. (2002), Little Ice Age, in Encyclopedia of Global Environmental Change, vol. 1, The Earth System: Physical and Chemical Dimensions of Global Environmental Change, edited by M. C. MacCracken and J. S. Perry, pp. 504-509, John Wiley, Chichester, U. K.

McEwen, L. J. (2006), Flood seasonality and generating conditions in the Tay catchment, Scotland from 1200 to present, Area, 38(1), 47-64, doi:10.1111/j.1475-4762.2006.00659.x.

Mudelsee, M., M. Börngen, G. Tetzlaff, and U. Grünewald (2003), No upward trends in the occurence of extreme floods in central Europe, Nature, 425(6954), 166-169, doi:10.1038/nature01928.

Müller, J., and W. Sigl (1977), Morphologie und rezente Sedimentation des Ammersees, Neues Jahrb. Geol. Palaeontol. Abh., 154(2), 155-185.

Petrow, T., and B. Merz (2009), Trends in flood magnitude, frequency and seasonality in Germany in the period 1951-2002, J. Hydrol., 371(1-4), 129-141, doi:10.1016/j.hydrol.2009.03.024.

Reimer, P. J., et al. (2004), Residual $\Delta^{14} \mathrm{C}$ around 1000 year moving average of IntCal04, Radiocarbon, 46(3), 1029-1058.

Siegenthaler, C., and M. Sturm (1989), Die Häufigkeit von Ablagerungen extremer Reusshochwasser. Die Sedimentationsgeschichte im Urnersee seit dem Mittelalter, Mitt. Bundesamt Wasserwirtsch., 4, 127-139.

Solanki, S. K., I. G. Usoskin, B. Kromer, M. Schüssler, and J. Beer (2004), Unusual activity of the Sun during recent decades compared to the previous 11,000 years, Nature, 431(7012), 1084-1087, doi:10.1038/ nature 02995 .

Spötl, C., and T. W. Vennemann (2003), Continuous-flow isotope ratio mass spectrometric analysis of carbonate minerals, Rapid Commun. Mass Spectrom., 17(9), 1004-1006, doi:10.1002/rcm.1010.

Stabel, H. H. (1986), Calcite precipitation in Lake Constance: Chemical equilibrium, sedimentation, and nucleation by algae, Limnol. Oceanogr., 31(5), 1081-1094.

Stuiver, M., and H. A. Polach (1977), Discussion: Reporting of ${ }^{14} \mathrm{C}$ Data, Radiocarbon, 19(3), 355-363.

Sturm, M., and A. Matter (1978), Turbidites and varves in Lake Brienz (Switzerland): Deposition of clastic detritus by density currents, Spec. Publ. Int. Assoc. Sediment, 2, 147-168.

Svensmark, H. (2000), Cosmic rays and Earth's climate, Space Sci. Rev., 93(1-2), 175-185, doi:10.1023/A:1026592411634.

Svensmark, H., and E. Friis-Christensen (1997), Variation of cosmic ray flux and global cloud coverage-A missing link in solar-climate relationships, J. Atmos. Sol. Terr. Phy., 59(11), 1225-1232, doi:10.1016/ S1364-6826(97)00001-1.

Swierczynski, T., S. Lauterbach, P. Dulski, and A. Brauer (2009), Die Sedimentablagerungen des Mondsees (Oberösterreich) als ein Archiv extremer Abflussereignisse der letzten 100 Jahre, in Alpine Space - Man and Environment, vol. 6, Klimawandel in Österreich, pp. 115-126, Innsbruck Univ. Press, Innsbruck, Austria.

Thorndycraft, V. R., and G. Benito (2006), The Holocene fluvial chronology of Spain: Evidence from a newly compiled radiocarbon database, Quat. Sci. Rev., 25(3-4), 223-234, doi:10.1016/j.quascirev.2005.07.003.

Thorndycraft, V. R., Y. Hu, F. Oldfield, P. R. J. Crooks, and P. G. Appleby (1998), Individual flood events detected in the recent sediments of the Petit Lac d'Annecy, eastern France, Holocene, 8(6), 714-746, doi:10.1191/095968398668590504.

Usoskin, I. G., S. K. Solanki, M. Schüssler, K. Mursula, and K. Alanko (2003), Millennium-scale sunspot number reconstruction: Evidence for an unusual active sun since the 1940s, Phys. Rev. Lett., 91(21), 211101, doi:10.1103/PhysRevLett.91.211101.

van Geel, B., O. M. Raspopov, H. Renssen, J. van der Plicht, V. A. Dergachev, and H. A. J. Meijer (1999), The role of solar forcing upon climate change, Quat Sci. Rev., 18(3), 331-338, doi:10.1016/ SO277-3791(98)00088-2.

von Grafenstein, U., H. Erlenkeuser, J. Müller, and A. KleinmannEisenmann (1992), Oxygen isotope records of benthic ostracods in Bavarian lake sediments, Naturwissenschaften, 79(4), 145-152, doi:10.1007/BF01134431.

von Grafenstein, U., H. Erlenkeuser, J. Müller, P. Trimborn, and J. Alefs (1996), A 200 year mid-European air temperature record preserved in lake sediments: An extension of the $\delta^{18} \mathrm{O}_{\mathrm{p}}$-air-temperature relation into the past, Geochim. Cosmochim. Ac., 60(21), 4025-4036, doi:10.1016/ SOO16-7037(96)00230-X.

von Grafenstein, U., H. Erlenkeuser, A. Brauer, J. Jouzel, and S. J. Johnson (1999), A mid-European decadal isotope-climate record from 15,500 to 5000 years B.P., Science, 284(5420), 1654-1657, doi:10.1126/science. 284.5420 .1654$.

Waple, A. M., M. E. Mann, and R. S. Bradley (2002), Long-term patterns of solar irradiance forcing in model experiments and proxy based surface temperature reconstructions, Clim. Dyn., 18(7), 563-578, doi:10.1007/ s00382-001-0199-3.

A. Brauer, M. Czymzik, P. Dulski, and B. Plessen, Section 5.2: Climate Dynamics and Landscape Evolution, GFZ German Research Centre for Geosciences, Telegrafenberg, D-14473 Potsdam, Germany. (czymzik@) gfz-potsdam.de)

R. Naumann, Section 4.2: Inorganic and Isotope Geochemistry, GFZ German Research Centre for Geosciences, Telegrafenberg, D-14473 Potsdam, Germany.

U. von Grafenstein, Laboratoire des Sciences du Climat et de l'Environnement, UMR CEA-CNRS, Orme des Mersiers, F-91191 Gif-sur-Yvette, France. 